\title{
Nanoparticle exposure driven circulating bioactive peptidome causes systemic inflammation and vascular dysfunction
}

Ekaterina Mostovenko', Tamara Young², Pretal P. Muldoon ${ }^{1}$, Lindsey Bishop ${ }^{3}$, Christopher G. Canal' ${ }^{1}$, Aleksandar Vucetic ${ }^{1}$, Patti C. Zeidler-Erdely ${ }^{3}$, Aaron Erdely ${ }^{3}$, Matthew J. Campen ${ }^{2}$ and Andrew K. Ottens ${ }^{1 *}$ (DD

\begin{abstract}
Background: The mechanisms driving systemic effects consequent pulmonary nanoparticle exposure remain unclear. Recent work has established the existence of an indirect process by which factors released from the lung into the circulation promote systemic inflammation and cellular dysfunction, particularly on the vasculature. However, the composition of circulating contributing factors and how they are produced remains unknown. Evidence suggests matrix protease involvement; thus, here we used a well-characterized multi-walled carbon nanotube (MWCNT) oropharyngeal aspiration model with known vascular effects to assess the distinct contribution of nanoparticle-induced peptide fragments in driving systemic pathobiology.
\end{abstract}

Results: Data-independent mass spectrometry enabled the unbiased quantitative characterization of 841 significant MWCNT-responses within an enriched peptide fraction, with 567 of these factors demonstrating significant correlation across animal-paired bronchoalveolar lavage and serum biofluids. A database search curated for known matrix protease substrates and predicted signaling motifs enabled identification of 73 MWCNT-responsive peptides, which were significantly associated with an abnormal cardiovascular phenotype, extracellular matrix organization, immune-inflammatory processes, cell receptor signaling, and a MWCNT-altered serum exosome population. Production of a diverse peptidomic response was supported by a wide number of upregulated matrix and lysosomal proteases in the lung after MWCNT exposure. The peptide fraction was then found bioactive, producing endothelial cell inflammation and vascular dysfunction ex vivo akin to that induced with whole serum. Results implicate receptor ligand functionality in driving systemic effects, exemplified by an identified 59-mer thrombospondin fragment, replete with CD36 modulatory motifs, that when synthesized produced an antiangiogenic response in vitro matching that of the peptide fraction. Other identified peptides point to integrin ligand functionality and more broadly to a diversity of receptor-mediated bioactivity induced by the peptidomic response to nanoparticle exposure.

Conclusion: The present study demonstrates that pulmonary-sequestered nanoparticles, such as multi-walled carbon nanotubes, acutely upregulate a diverse profile of matrix proteases, and induce a complex peptidomic response across lung and blood compartments. The serum peptide fraction, having cell-surface receptor ligand properties, conveys peripheral bioactivity in promoting endothelial cell inflammation, vasodilatory dysfunction and inhibiting angiogenesis. Results here establish peptide fragments as indirect, non-cytokine mediators and putative biomarkers of systemic health outcomes from nanoparticle exposure.

Keywords: MWCNT, Nanomaterial, Lung, Peptidome, MMP, Mass spectrometry, Carbon nanotubes, Inflammation, Vascular dysfunction, Thrombospondin, Nanoparticles

\footnotetext{
*Correspondence: akottens@vcu.edu

'Department of Anatomy and Neurobiology, Virginia Commonwealth

University, Box 980709, Richmond, VA 23298-0709, USA

Full list of author information is available at the end of the article
}

(c) The Author(s). 2019 Open Access This article is distributed under the terms of the Creative Commons Attribution 4.0 International License (http://creativecommons.org/licenses/by/4.0/), which permits unrestricted use, distribution, and reproduction in any medium, provided you give appropriate credit to the original author(s) and the source, provide a link to the Creative Commons license, and indicate if changes were made. The Creative Commons Public Domain Dedication waiver (http://creativecommons.org/publicdomain/zero/1.0/) applies to the data made available in this article, unless otherwise stated. 


\section{Background}

Ultrafine $(<0.1 \mu \mathrm{m})$ particulate represents a unique toxicological burden with the ability to circumvent or frustrate normal mucociliary clearance, deposit deep into alveolar regions, and produce prolonged retention and enhanced toxicity [1-3]. Yet the health implications of environmental or occupational nanoscale particulate extend well beyond the lung, with inflammation and dysfunction evident after exposure in the cardiovasculature and other organs like the brain [4-7]. Among engineered nanoparticles, multi-walled carbon nanotubes (MWCNT) stand out as particularly hazardous given their durability and fibrous shape akin to asbestos [8]. Systemic inflammation [9], atherosclerosis [10], vascular dysfunction [11], and even cognitive deficits [12] have been reported from MWCNT pulmonary exposure, impacting other organ systems such as the liver, kidneys [13] and brain [14]. Particle translocation is one possible explanation for the extensive systemic response to nanoscale particulate $[13,15,16]$. However, data on translocation from the lung can be ambiguous for insoluble materials like MWCNT, with several studies showing no evidence for it $[17,18]$. With detailed tracking of MWCNT following oropharyngeal aspiration, Mercer et al. showed only a modest $1 \%$ clearance to the lymphatics within $24 \mathrm{~h}$, with less than $0.01 \%$ MWCNT transferred to other organs [19]. Implicated is an indirect mechanism underlying acute systemic effects that may extend to other partly soluble materials. Brook et al. proposed that proinflammatory mediators travel from the lung into circulation, the so-called "systemic spill-over" mechanism [6]. Yet cardiovascular deficits from nanoparticle exposure have been reported without pulmonary inflammation [20, $21]$. This suggests that extra-pulmonary outcomes are mediated by as-yet-unknown, non-cytokine, bioactive molecules released into the circulation [22, 23].

Cardiovascular deficits are among the earliest and widest reported systemic effects of nanoparticle exposure [10, 24]. Work from our group and others demonstrates impaired endothelium-dependent relaxation when naïve aortic vessels are treated with serum from MWCNT-exposed animals [25, 26]. Yet, vessels from CD36 knockout animals were largely unaffected by serum from wild-type mice exposed to MWCNT [25]. In reverse, vasodilatory deficits in naïve aortas were largely muted when incubated with serum from thrombospondin (TSP) knockout animals exposed to MWCNT [26], pointing to a TSP-CD36 mediated effect. However, this does not explain how treatment with serum from MWCNT-exposed matrix metalloproteinase 9 (MMP9)-null mice in part rescues vasodilation in naïve vessels [25]. The latter result speaks to the broader relevance of matrix protease activation within the lung and its potential involvement in transducing systemic effects after pulmonary insult $[27,28]$. Thus, we posited that protease-generated peptide fragments represented an untested bioactive fraction in promoting systemic pathobiology. MWCNT-induced lung responses may activate a diverse set of matrix proteases to foster the release of peptide products across the lung-blood barrier, which may mediate at least part of the extra-pulmonary burden. Recent advances in data-independent quantitative mass spectrometry provides an ideal platform to assess endogenous unknown products [29]. Here, we used unbiased mass spectrometry to analyze paired bronchoalveolar lavage and serum biofluids to characterize Mitsui-7 MWCNT-aspiration induced peptidomic fragments introduced into circulation $4 \mathrm{~h}$ after insult with relevance to ongoing lung pathobiology. The bioactive contribution of the serum peptide fraction was functionally interrogated ex vivo, with results supporting a newly proposed peptide-mediated indirect mechanism for the peripheral effects of nanoparticle lung exposure.

\section{Methods}

Animal model and sample collection

Specific pathogen-free male C57BL/6 J mice (Jackson Laboratory) were housed in an Association for Assessment and Accreditation of Lab Animal Care International approved animal facility at the National Institute for Occupational Safety and Health. Animal care and use procedures were conducted in accordance with the "Public Health Service Policy on Humane Care and Use of Laboratory Animals" and the "Guide for the Care and Use of Laboratory Animals". Food and water were provided ad libitum in ventilated cages in a temperature and humidity controlled environment with a 12-h light/dark cycle. Eight-week-old C57BL/6 J mice, were exposed to MWCNT (Mitsui-7, Hodogaya, Japan, $>99 \%$ carbon purity) via oropharyngeal aspiration at $0 \mu \mathrm{g}, 10 \mu \mathrm{g}$, or $40 \mu \mathrm{g}$ ( $n=6$ per group) [30]. The MWCNT material was found negative for LPS using a ToxinSensor Chromagenic LAL Assay Kit (GenScript). MWCNT was prepared in dispersion media (DM) consisting of mouse serum albumin $(0.6 \mathrm{mg} / \mathrm{mL})$ and 1,2-dipalmitoyl-sn-glycero-3-phosphocholine $(10 \mu \mathrm{g} / \mathrm{mL})$. The average MWCNT was $49 \mathrm{~nm}$ in diameter and $3.86 \mu \mathrm{m}$ in length (geometric $\mathrm{SD}=1.94$ ) [30]. Matched serum and bronchoalveolar lavage fluid (BALF) were collected $4 \mathrm{~h}$ following aspiration under anesthesia as previously described [23]. The $4 \mathrm{~h}$ collection time was selected here to remain consistent with prior published work using this model that demonstrated in vivo and ex vivo vascular outcomes of MWCNT exposure [14, 23, 25].

\section{Endogenous peptide enrichment and mass spectrometry}

Matched serum and BALF were processed via the same protocol with proportional adjustment for their different starting volumes of $40 \mu \mathrm{l}$ for serum and $120 \mu \mathrm{l}$ for BALF given pilot results showing a 3-4 fold difference in 
peptide concentration. Biofluids were clarified by centrifugation through a $0.22 \mu \mathrm{m}$ Ultrafree-MC filtration unit (EMDMillipore, Billerica, MA) using manufacturer instructions. Samples were then denatured for $30 \mathrm{~min}$ at room temperature (18 $\mathrm{mM}$ TCEP final concentration) in presence of HALT inhibitor cocktail (Thermo Scientific, Rockford, IL) and 20\% final concentration acetonitrile. Reduced thiols were acetylated with iodoacetamide at a final concentration $30 \mathrm{mM}$ with a $30 \mathrm{~min}$ incubation in the dark at room temperature. Samples were transferred onto pre-cleaned MicroCon YM-30 centrifugal filter units (EMDMillipore) and centrifuged per manufacturer instructions to isolate endogenous peptides from proteins and vesicles. The retentate was acidified using $0.4 \%$ formic acid to further disrupt peptide binding with collection via a second centrifugation of the filter unit. Resultant peptide-enriched filtrates were loaded $(4.5 \mu \mathrm{l})$ onto a Symmetry C18 reversed-phase column to remove lipids, reagents and salts. The peptidomic fraction for each serum sample was separated using a NanoAcquity UPLC (Waters, Milford, Massachusetts) online with a Waters Synapt G2 tandem mass spectrometer as described previously [31]. Briefly, the peptide fraction was separated on a $150 \mathrm{~mm} \times 75 \mu \mathrm{m}$ HSS T3 reversed-phase capillary column at $55^{\circ} \mathrm{C}$ for $65 \mathrm{~min}$ with an elution gradient from 6 to $44 \%$ acetonitrile in water $(0.1 \%$ formic-acid modified). The Synapt G2 was operated with ion mobility enabled data-independent acquisition (UDMSe) at a nominal 25,000 resolving power [32]. The precursor mass range was optimized between 400 and $1800 \mathrm{~m} / \mathrm{z}$ to account for larger endogenous peptides.

\section{Mass spectral data processing and analysis}

Spectra processing was performed employing PLGS v3.0.2 software (Waters) as described previously [31]. Ion tables for matched BALF and serum samples were clustered together in matching retention time $( \pm 2 \mathrm{~min})$, drift time ( \pm 4 bins), and ion mass $( \pm 12 \mathrm{ppm})$ with EndogeSeq. Results were filtered to include only reproducible ion events observed in two-thirds or more of the biological replicates. For ions categorically falling below the limit of detection across all replicates in a group, a randomly generated set of values was imputed with a mean and coefficient of variance equating the limit of quantification observed across that group's replicates [33]. The clustered ion matrix was then median centered and $\log _{2}$ transformed. Fold changes were calculated relative to the mean for the DM $(0 \mu \mathrm{g}$ MWCNT) vehicle control group. Ions found significantly responsive to MWCNT treatment in serum and BALF biofluids were assessed to identify an overlap with known MMP and ADAM/TS substrates using the MEROPS database [34] and with proteins with predicted secretory domains using the SignalP algorithm [35]. The search workflow included no enzyme specificity for assessing endogenous measures with precursor and product ion match limits of 6 and 12 $\mathrm{ppm}$, respectively. A random-decoy database method was used to control false peptide identification to under a $10 \%$ false discovery rate (FDR) using the peptide score, which is highly dependable given the high-resolution tandem mass spectral measures [36]. Matched product ion spectra were visualized using mMass software [37]. Identified peptides were further characterized using the enrichment analysis tools in ToppGene [38] and STRING [39] online software suites, with results adjusted to a 5\% FDR.

\section{Matrix protease expression analysis in the lung}

Four hours after DM vehicle, $10 \mu \mathrm{g}$ or $40 \mu \mathrm{g}$ MWCNT oropharyngeal aspiration, mice were euthanized and their left lung lobe was ligated while bronchoalveolar lavage was performed on the right lung lobe. BALF and whole lung homogenates were assessed for MMP9 protein levels using an enzyme linked immunosorbent assays according to manufacturer's instructions (Boster, Pleasanton, CA).

Broader matrix protease and tissue inhibitors of metalloproteinases were assessed in an existing lung tissue microarray dataset. Animals were exposed for $4 \mathrm{~h}$ to Mitsui-7 MWCNT by inhalation to deposit approximately $4 \mu \mathrm{g}$ or $40 \mu \mathrm{g}$ as previously described [40]. Lung tissue was assessed for gene expression on an Illumina platform as previously described [40]. In summary, 375 ng of RNA was used to generate cRNA for hybridization to the arrays. MouseRef- 8 BeadChips were analyzed on an Illumina BeadStation 500G reader (Illumina, San Diego, CA). Data processing and differential expression analysis was performed using the Limma $\mathrm{R}$ package as described elsewhere [41].

\section{Serum cumulative inflammatory potential assay}

Mouse endothelial cells were obtained from a commercial vendor (Cell Biologics, Chicago, IL) and maintained according to manufacturer's recommendations at $37^{\circ} \mathrm{C}$ and $5 \% \mathrm{CO}_{2}$ with complete endothelial cell medium supplemented with $6 \%$ fetal bovine serum. All experiments were performed between passages 3 and 8 . Assays were batched by exposure to enhance consistency and comparability across samples. Obtained endothelial cells were treated $4 \mathrm{~h}$ in vitro with the enriched peptide fraction from MWCNT exposed or DM control mouse serum to assess the serum cumulative inflammatory potential as previously published [42]. In short, endothelial cells were serum starved overnight and incubated with culture media supplemented at a final concentration of $5 \%$ subject peptide fraction for $4 \mathrm{~h}$ and harvested. RNA was isolated using the RNeasy Mini Kit (QIAGEN, Germantown, MD) and reverse transcribed prior to quantitative real-time PCR. Expression of interleukin 6 (Il6), C-C motif 
chemokine ligand 2 ( $\mathrm{Ccl} 2), \mathrm{C}-\mathrm{C}$ motif chemokine ligand 5 (Ccl5), vascular cell adhesion molecule 1 (Vcam1), (Icam1), tumor necrosis factor alpha (Tnfa), and transforming growth factor beta ( $T g f b$ ) (Applied Biosystems, Foster City, CA) were measured using the TaqmanR Gene Expression protocol (ThermoScientific, Waltham, MA) following the manufacturer's instructions. Relative gene expression normalized to the endogenous control TATA-Box Binding Protein gene was analyzed using the $2^{-\Delta \Delta C T}$ method.

\section{Myography vascular function assay}

Analysis was performed as described previously [25]. Briefly, $2 \mathrm{~mm}$ segments of thoracic aorta rings were isolated from naïve C57BL/6 J mice, cleaned of connective tissue and mounted in a 4-chamber multi-wire myograph (610 M; Danish Myo Technology A/S, Aarhus, Denmark) submerged within solutions continuously maintained at $37^{\circ} \mathrm{C}$ and bubbled with $21 \% \mathrm{O}_{2}-5 \% \mathrm{CO}_{2}$ in nitrogen. Naïve vessels were initially submerged in physiological saline solution (PSS): $4.7 \mathrm{mM} \mathrm{KCl,} 119.0$ $\mathrm{mM} \mathrm{NaCl}, 25.0 \mathrm{mM} \mathrm{NaHCO} 3,5.5 \mathrm{mM}$ glucose, $1.2 \mathrm{mM}$ $\mathrm{MgSO}_{4}, 1.2 \mathrm{mM} \mathrm{KH_{2 }} \mathrm{PO}_{4}, 0.025 \mathrm{mM}$ EDTA, $2.5 \mathrm{mM}$ $\mathrm{CaCl}_{2}$ and equilibrated for $30 \mathrm{~min}$. Vessel viability was then tested by assessing a contractile response to a high-concentration potassium chloride physiological saline solution (KPSS): $58.9 \mathrm{mM} \mathrm{KCl}, 64.9 \mathrm{mM} \mathrm{NaCl}, 25.0$ $\mathrm{mM} \mathrm{NaHCO}_{3}, 5.5 \mathrm{mM}$ glucose, $1.2 \mathrm{mM} \mathrm{MgSO}_{4}, 1.2 \mathrm{mM}$ $\mathrm{KH}_{2} \mathrm{PO}_{4}, 0.025 \mathrm{mM}$ EDTA, $2.5 \mathrm{mM} \mathrm{CaCl}$. Afterwards, all vessels were washed four times with PSS and equilibrated for $30 \mathrm{~min}$. The naïve vessels were then treated and allowed to stabilize ex vivo in PSS spiked at $1 \%(\mathrm{v} / \mathrm{v})$ with the serum peptide fraction derived from the animals previously exposed to MWCNT or DM in vivo. Then the cumulative concentration-response curve to acetylcholine $\left(10^{-9}\right.$ to $\left.10^{-4} \mathrm{M}\right)$ was acquired using LabChart software.

\section{Electrical wound-healing angiogenesis assay}

Mouse endothelial cells were plated at $2 \times 10^{5}$ cells $/ \mathrm{mL}$ and grown to confluence on a 96-well 96W1E+ electrode plate coated with $0.01 \%$ poly-L-lysine for an Electric Cell-Substrate Impedance System (ECIS; Applied Biophysics, Troy, NY). Transmembrane resistive impedance was recorded continuously $(4 \mathrm{~Hz})$ until establishment of tight intracellular contact. Synthetic TSP $_{402-460}$ peptide or the serum peptide fraction derived from the animals previously exposed to MWCNT or DM in vivo were added to each well at $5 \%(\mathrm{v} / \mathrm{v})$ in media. After a 4-h in vitro treatment, a $1 \mathrm{~mA}$ current pulse was passed through a central electrode on each well to instigate a wound. Angiogenesis regrowth towards the center of the well was then monitored as the recovery of transmembrane impedance. The ECIS assay was preferred to the physical scratch method, as the protein coating on the wells is unperturbed by the electrical stimulus. Results were reported as the average normalized impedance per hour as a percent of baseline impedance from the hour prior to treatment.

\section{Exosome characterization}

Serum exosomes were purified first by passing through a $0.22 \mu \mathrm{m}$ Ultrafree $\mathrm{MC}$ centrifugal unit to eliminated larger-sized debris and apoptotic bodies and then by size-exclusion chromatography to resolve from lipovesicles and serum protein using a $5 \mathrm{~mm} \times 10 \mathrm{~cm}$ column packed with Sephacryl S-500 HR media (GE Bio-Sciences, Uppsala, Sweden) at $0.2 \mathrm{~mL} / \mathrm{min}$ in PBS buffer. The optimized exosome fraction was collected from 3 to $5 \mathrm{~min}$ and assessed using a Zetasizer Nano S90 (Malvern Panalytical, Malvern, UK). Exosome samples were also fixed in $4 \%$ paraformaldehyde in $0.15 \mathrm{M}$ sodium cacodylate buffer 1:1 (v:v), a $10 \mu \mathrm{l}$ drop was placed onto parafilm and covered with a formvar-coated grid. Mounted samples were rinsed with PBS and fixed again with $1 \%$ glutaraldehyde in $0.1 \mathrm{M}$ sodium cacodylate. The sample was then rinsed and negative stained using $0.5 \%$ aqueous uranyl acetate and air dried overnight. A JEOL JEM-1230 transmission electron microscope with Gatan Orius SC1000 side-mount CCD camera was used for imaging.

\section{Gene expression analysis examined for c-Jun regulatory targets}

RNA was extracted from naïve endothelial cells, as described earlier for the serum cumulative inflammatory potential assay, after a 4-h in vitro treatment with serum collected 4-h after exposing mice in vivo to DM vehicle, $10 \mu \mathrm{g}$, and $40 \mu \mathrm{g}$ MWCNT. Extracted RNA was analyzed using Affymetrix GeneChip Mouse 4302.0 arrays according to the manufacturer's protocol and as described previously [14]. Briefly, $1 \mu \mathrm{g}$ of total RNA was used to produce biotinylated cRNA, synthesized by in vitro transcription using the GeneChip IVT Labeling Kit (Affymetrix) and fragmented and hybridized to the Affymetrix GeneChip following the chip protocol. Arrays were scanned with an Affymetrix GeneChip Scanner 3000. Results meeting a minimal log change ratio of 0.5 from DM control and $p<0.01$ were then selected if known as c-Jun regulatory targets.

\section{Statistical analysis}

Statistical analysis of $\log _{2}$-transformed mass spectral peptide data was performed in MultiExperimentViewer v4.9 [43] using the one-way ANOVA function and the significance level corrected for multiple peptide measures to a 5\% FDR using the Benjamini-Hochberg method [44]. Statistically responsive peptides were assessed for intensity correlation across matched serum and BALF samples using linear regression analysis in SigmaPlot v13. MMP9 
ELISA and vesicular size results were assessed using one-way ANOVA with Holm-Sidak post hoc or one-way ANOVA on Ranks (for results with unequal variance) with Dunnett's post hoc testing for multiple comparisons in SigmaPlot. Serum cumulative inflammatory potential assay results were assessed by two-way ANOVA with dose and denaturing as factors and Holm-Sidak post hoc testing in SigmaPlot. Myography and ECIS results were assessed by two-way ANOVA with dose as the first factor and acetylcholine concentration (myography) or time (ECIS) as the second factor followed by Holm-Sidak post hoc testing in SigmaPlot. Microarray results were analyzed using the Limma $R$ package in Bioconductor v3.8, which uses linear regression models for each gene assessed for the Bayes moderated t-statistic and associated $p$-values, corrected for multiple testing using the Benjamini-Hockberg method. Data were plotted as the mean $\pm \mathrm{SE}$, with $\mathrm{n}$ denoting the number of biological replicates described per figure legend.

\section{Results \\ MWCNT-induced peptides overlap between the lung and circulation}

Enriched-peptide fractions from animal-matched serum and BALF specimens were isolated by size-fractionation and hydrophobic solid-phase extraction from proteinaceous and lipid components and assessed by data-independent mass spectrometry to identify cross-talk between the lung and circulation. As expected, the depth of detection was more limited for BALF (3767 reproducible measures), at $29 \%$ of that for serum (12,972 reproducible measures). The lavage procedure involves the rapid partition of the bronchoalveolar surface molecular mass into the lavage buffer for a dilute representation of the airway epithelial lining fluid, which limits recovery and assessment [45]. That said, 1712 , or nearly half of all reproducible measures assessed in BALF were detected within serum, demonstrating substantial overlap between the two compartments (Fig. 1a). Interestingly, more than half of the BALF-serum common measures (872 of the 1712) were exclusively detected either among replicate specimens from MWCNT or DM vehicle treatment groups, $613(70 \%)$ of those solely detected after MWCNT exposure (i.e., not in any specimens from DM treated animals). Statistically, 841 of 1712 species were responsive to MWCNT treatment at a 5\% FDR (Fig. 1b). Of those, 567 species also demonstrated a significant abundance correlation between BALF and serum: $10 \mu \mathrm{g}$ exposure, $\mathrm{R}=0.49, \mathrm{~F}=84.7, p<0.001 ; 40 \mu \mathrm{g}$ exposure $\mathrm{R}=$ $0.48, \mathrm{~F}=126.5, p<0.001$ (Fig. 1c). Thus, results here corroborated a robust molecular exchange between the lung and the circulation following MWCNT exposure allowing for further focused study of mediators of circulating systemic bioactivity in examining the identity of BALF-serum common factors as having more direct relevance to MWCNT-induced pulmonary pathobiology.

\section{MWCNT-responsive peptides identified from matrix protease substrates}

The fold-change response for the serum enriched-peptide fraction is illustrated across chromatographic and mass dimensions via 3D waterfall plots (Fig. 2a). Evident is a predominant increase in the assessed factors following $10 \mu \mathrm{g}$ or $40 \mu \mathrm{g}$ treatment (colored yellow to orange). The mass distribution fell between 1000 and $7000 \mathrm{Da}$, which was consistent for peptides, and generally exclusive of masses for small molecule metabolites below $1000 \mathrm{Da}$ and proteins above $7000 \mathrm{Da}$. The chromatographic retention profile reflected complete elution between 10 and 36\% acetonitrile, which was confirmatory of an enriched-peptide fraction and effective lipid removal. Figure 1b illustrated a greater number of increased peptide with the $40 \mu \mathrm{g}$ exposure relative to the $10 \mu \mathrm{g}$ MWCNT. Figure 2a illustrates that the majority of additional peptides with $40 \mu \mathrm{g}$ treatment are larger in mass, with greater density around $3 \mathrm{kDa}$ and $6.5 \mathrm{kDa}$. As larger mass fragments are more likely to include complete binding motifs, they may convey broader bioactivity.

The diversity of the peptidomic response suggests extensive proteolytic processing within the lung and subsequently in the circulation. Previously we demonstrated that MWCNT-induced vasodilatory deficits were dependent on MMP9 [25]. An MMP9 elevation in lung ( $F=5.9, p=$ $0.013)$ and BALF $(\mathrm{H}=11.6, p=0.003)$ support its potential involvement in peptide fragment generation (Fig. 2b). Yet MMP9 cleavage alone is insufficient to explain the shear multiplicity of peptides produced in response to MWCNT exposure. We thus looked farther afield in identifying peptides related to known substrates broadly across matrix proteases, including MMPs, ADAMs, and ADAMTSs. Resources available from the MEROPS peptidase project of the European Bioinformatics Institute provided a concise source of known substrates for these proteases that could then be used to significantly reduce the sequence search space [34], as beneficial to identifying endogenous peptide mass spectra [46]. Metalloproteases are further associated with extracellular signal-peptide release [47]. The SignalP resource from the Technical University of Denmark Bioinformatics unit extended our search capability to included predicted peptides of excreted proteins [35]. From these resources, 73 of the BALF-serum common measures found statistically responsive to MWCNT at one or both doses $(10 \mu \mathrm{g}$ or $40 \mu \mathrm{g})$ were identified (Fig. 2c and Table 1), relating the genesis of MWCNT induced peptides to known matrix protease substrates and secreted proteins. To substantiate further involvement of additional proteases, we mined an existing lung tissue microarray dataset exhibiting the effects of 

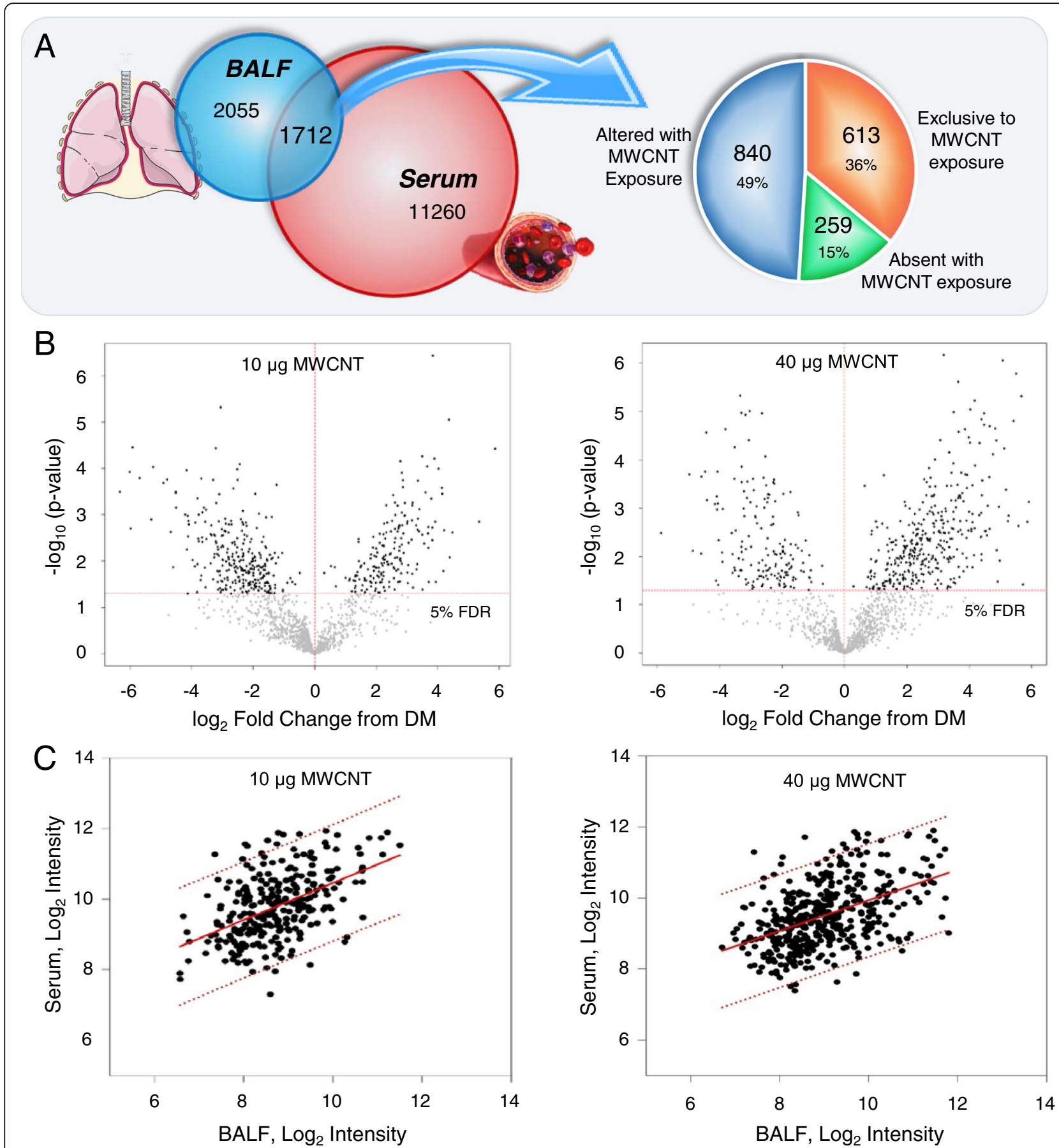

Fig. 1 MWCNT-responsive peptidome exhibited correlatory abundance between BALF and serum. The complex molecular response 4-h after MWCNT exposure within enriched-peptide fractions was assessed by mass spectrometry in animal-paired BALF and serum specimens. a Overlapping factors (1712) included 613 measures detected exclusively or 259 lost entirely from fluids in response to MWCNT exposure relative to DM control treatment with the remainder found modulated by exposure. $\mathbf{b}$ Volcano plots depicting the fold-change and significance level between MWCNT exposed and DM control animals for measures from the enriched-peptide fraction found across BALF and serum, $p$ adjusted to a 5\% FDR. c Linear regression plots of mass spectral intensity measures between animal-paired BALF and serum specimens. Plotted are those peptide measures that reached the 5\% FDR significance level. The regression line and 95\% confidence interval are show as solid and dashed lines, respectively. All data were generated using matched BALF and serum from $n=6$ replicate exposures per dose 


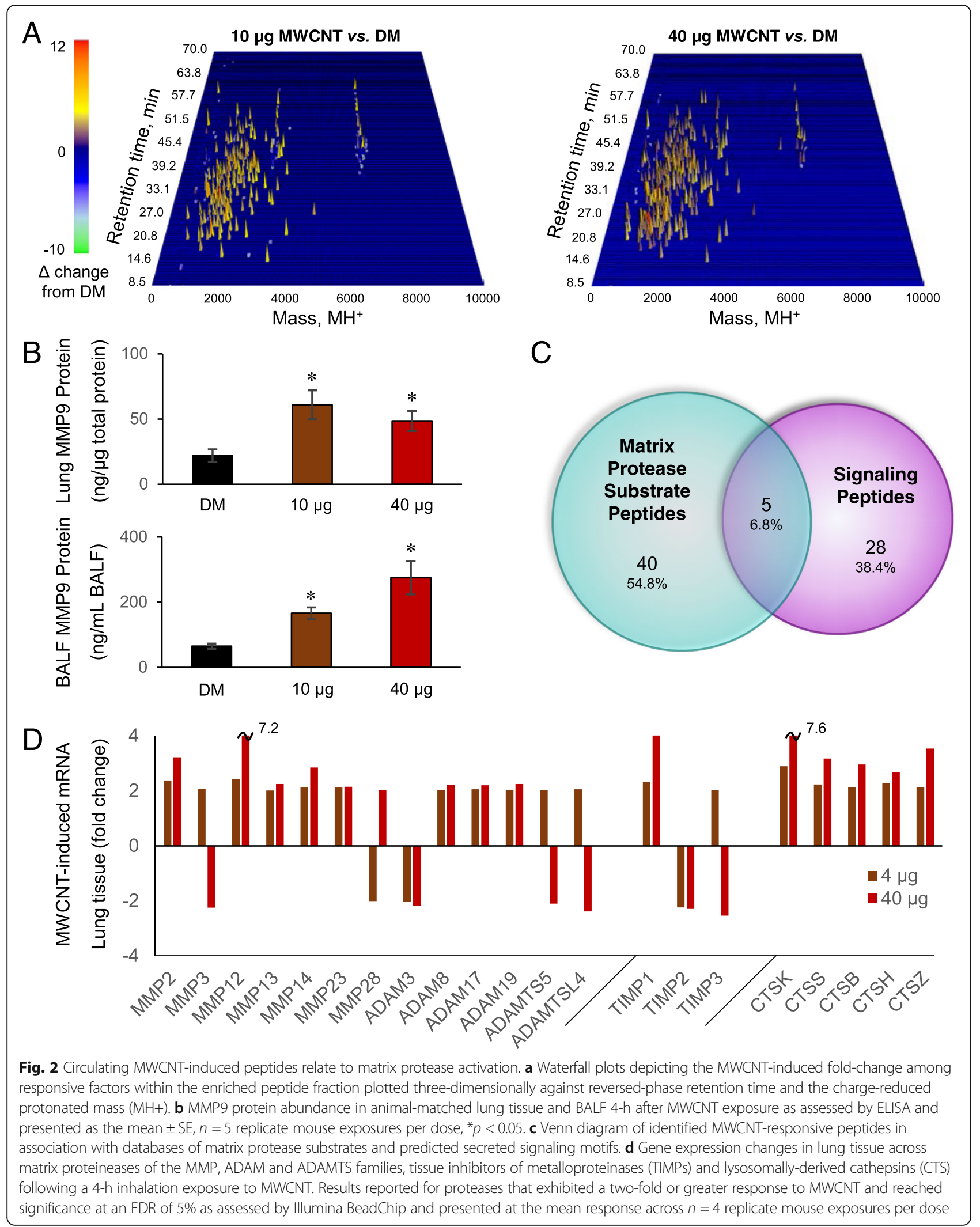




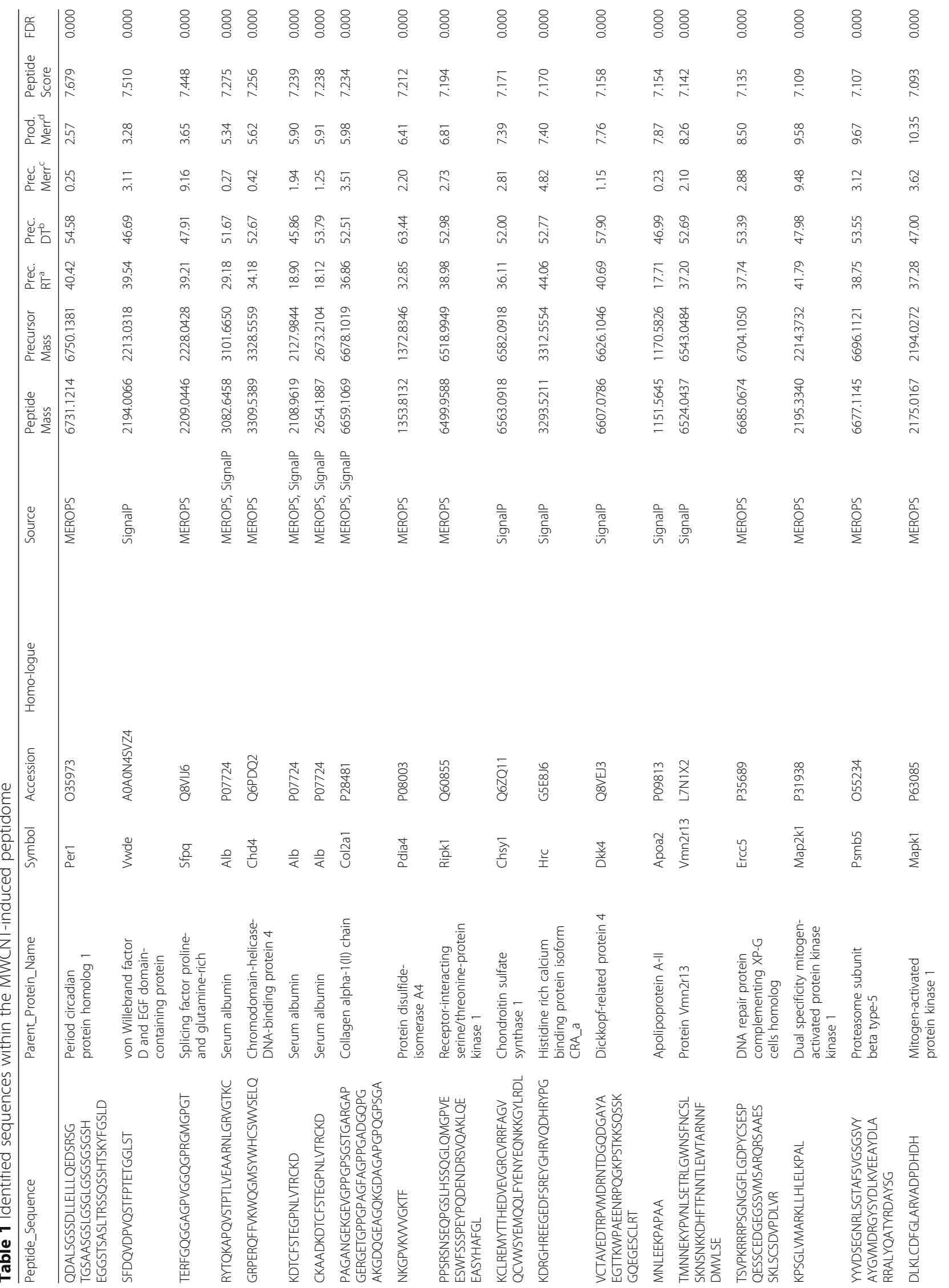




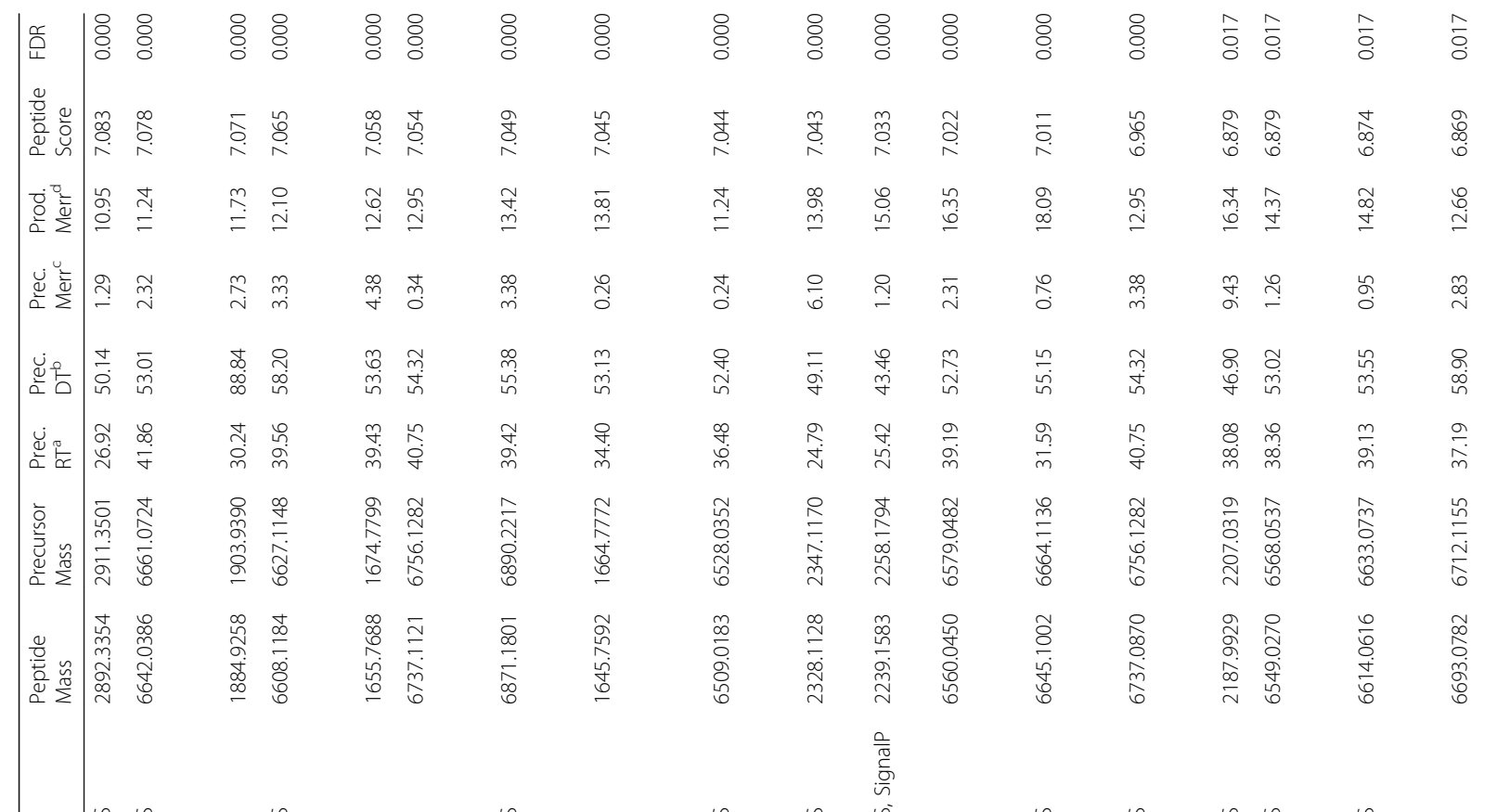

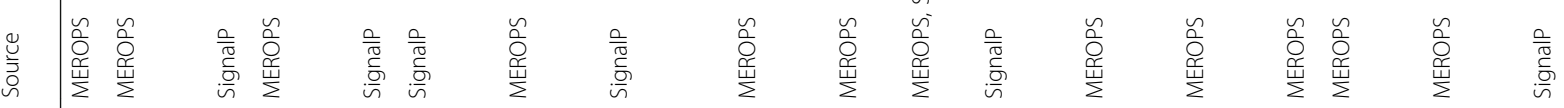

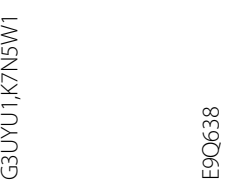

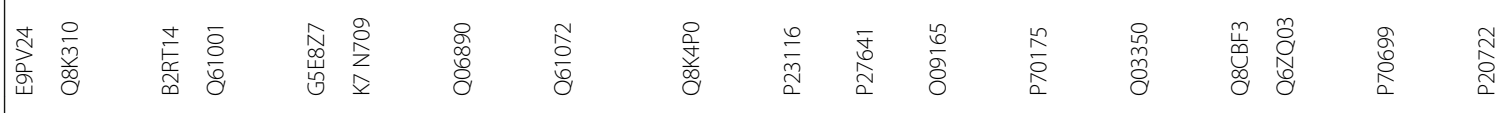

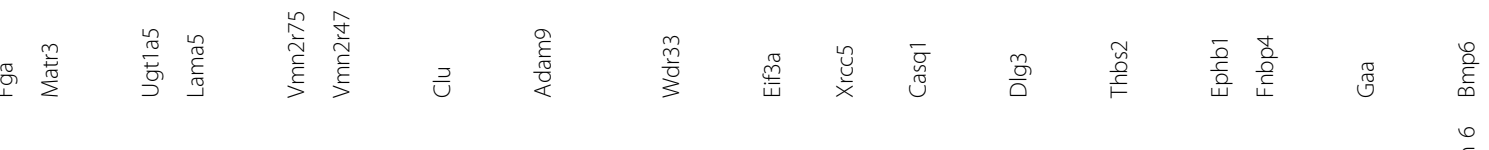

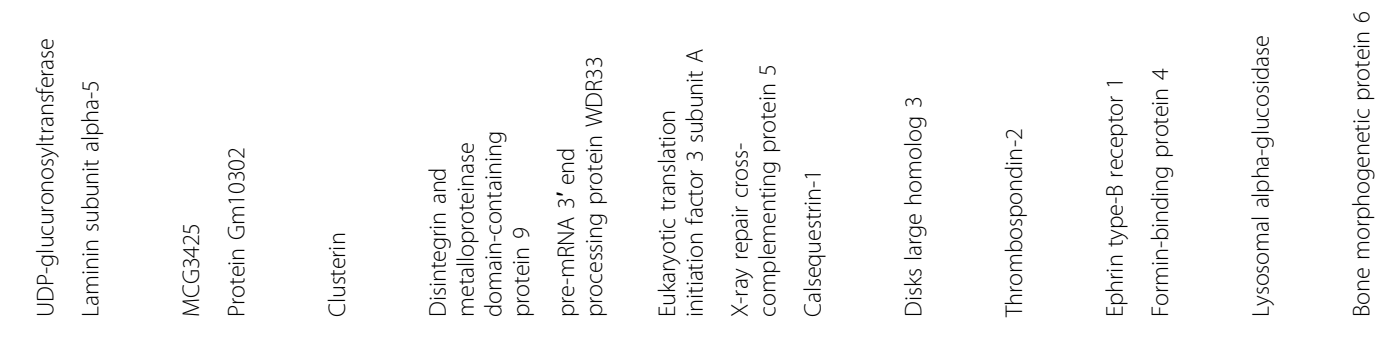

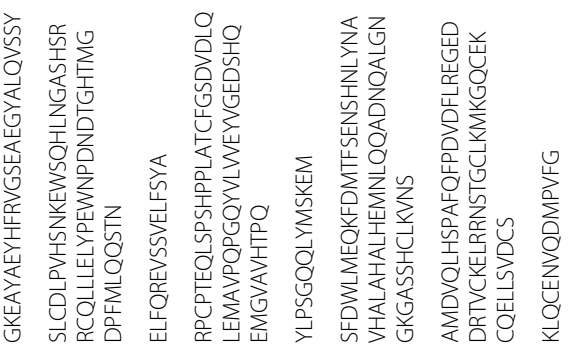

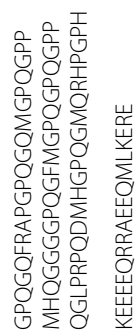

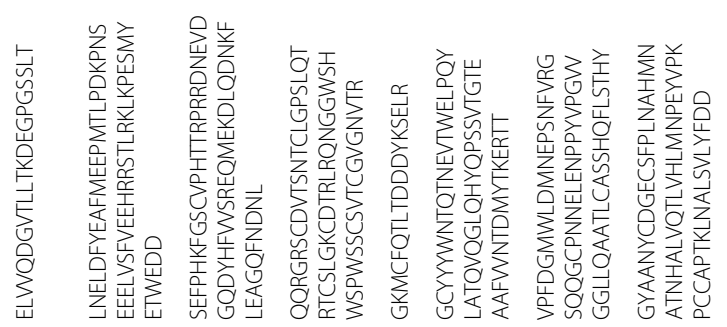




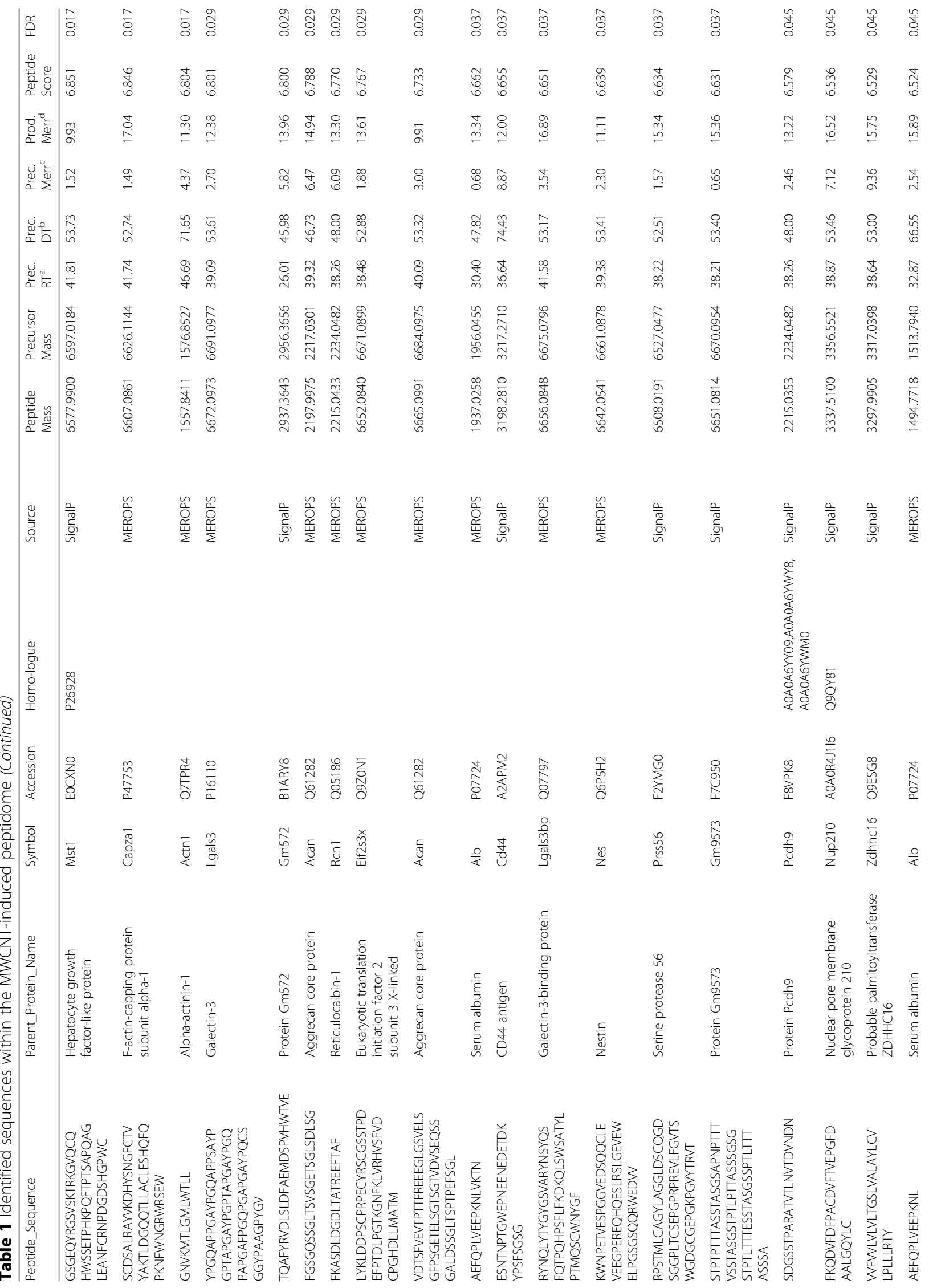




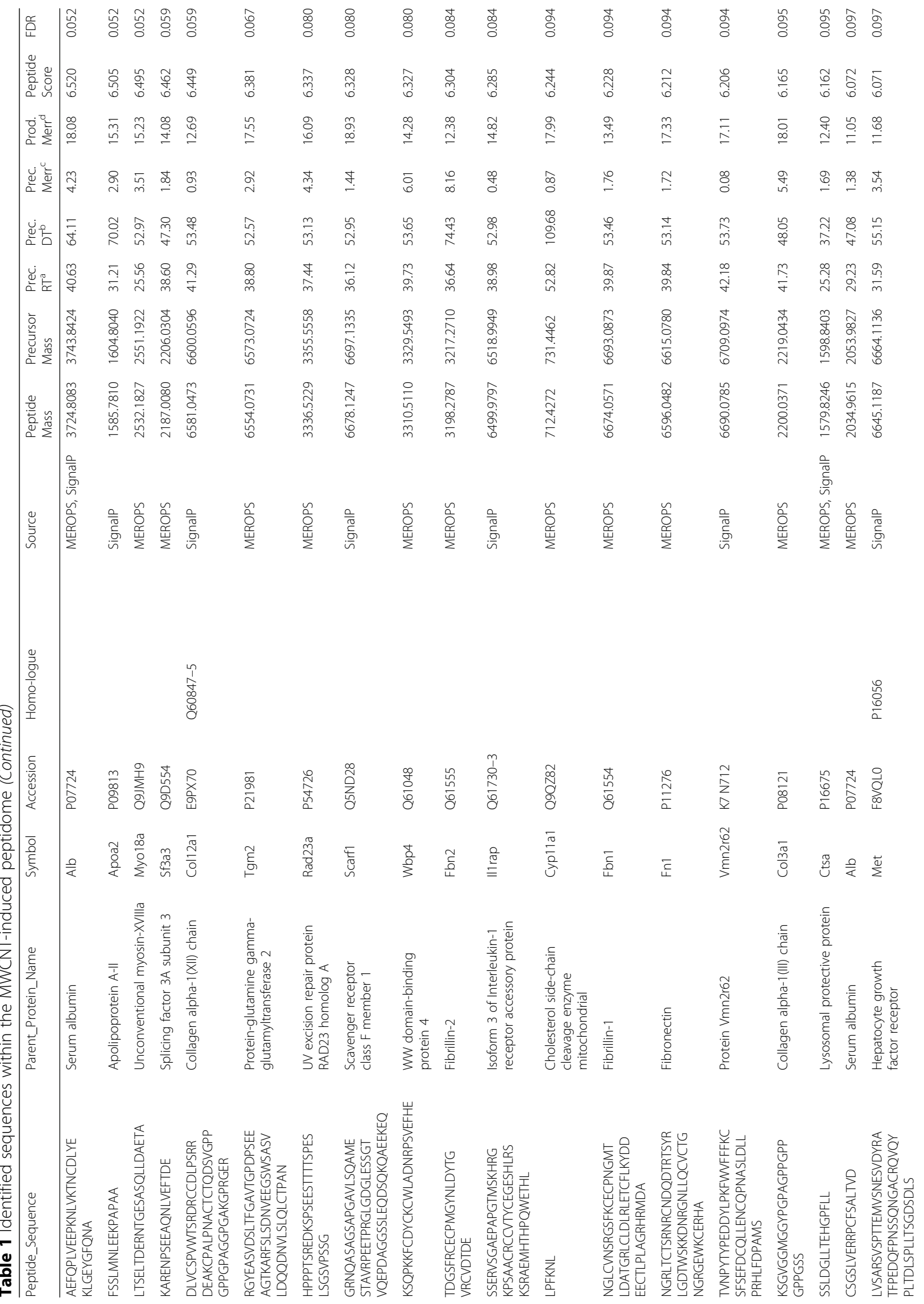




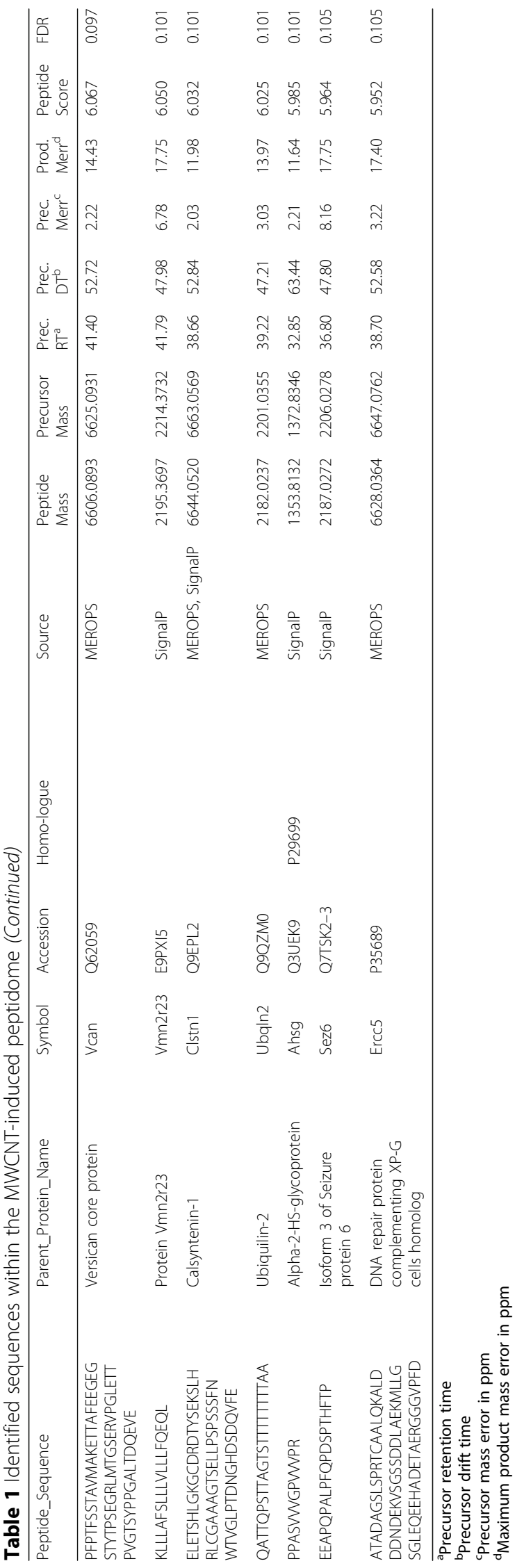




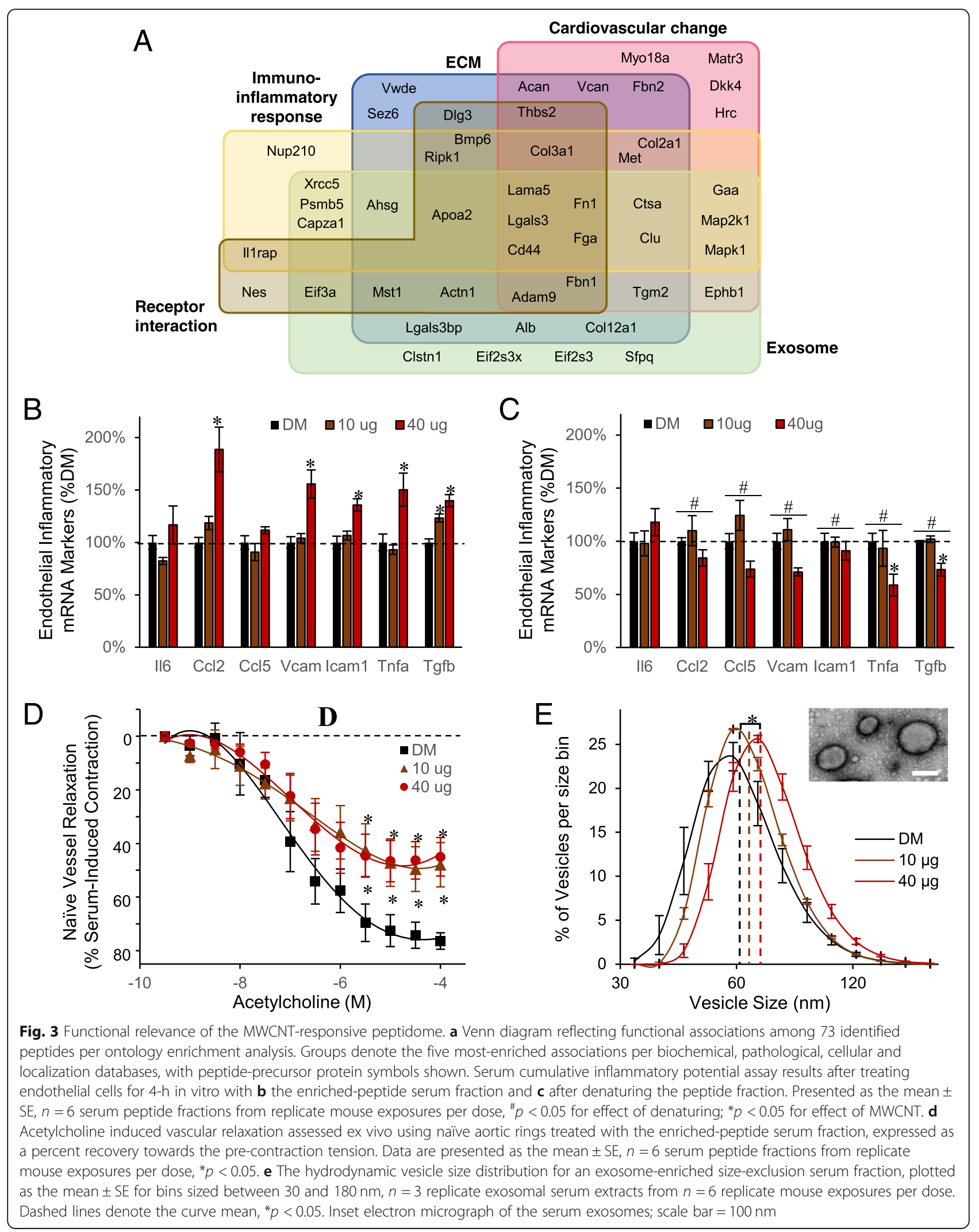


Table 2 Enriched cellular, molecular and phenotypes associated with the MWCNT-induced peptidome

\begin{tabular}{|c|c|c|c|c|}
\hline Category & ID & Name & q-value & \#Hits \\
\hline \multicolumn{5}{|c|}{ Extracellular matrix related } \\
\hline CellComp ${ }^{a}$ & GO:0005615 & Extracellular space & 4.15E-08 & 23 \\
\hline Pathway ${ }^{b}$ & M5889 & Genes encoding ECM and ECM-associated proteins & $5.048 \mathrm{E}-6$ & 20 \\
\hline BioProcess ${ }^{c}$ & GO:0030198 & Extracellular matrix organization & $3.174 \mathrm{E}-09$ & 15 \\
\hline \multicolumn{5}{|c|}{ Cardiovascular change related } \\
\hline MPhenotype $^{d}$ & MP:0002127 & Abnormal cardiovascular system morphology & 0.01783 & 24 \\
\hline BioProcess ${ }^{c}$ & GO:0072358 & Cardiovascular system development & $1.503 \mathrm{E}-5$ & 18 \\
\hline \multicolumn{5}{|c|}{ Immuno-inflammatory response related } \\
\hline BioProcess $^{c}$ & GO:0006955 & Immune response & 0.02223 & 14 \\
\hline Pathway ${ }^{\mathrm{b}}$ & 1269203 & Innate immune system & 0.007017 & 16 \\
\hline \multicolumn{5}{|c|}{ Receptor binding related } \\
\hline MolFun ${ }^{e}$ & GO:0005102 & Receptor binding & 0.002014 & 17 \\
\hline \multicolumn{5}{|c|}{ Exosome related } \\
\hline CellComp ${ }^{a}$ & GO:0070062 & Extracellular exosome & 4.43E-05 & 29 \\
\hline
\end{tabular}

Enrichment assessed in association with the following ontology database categories:

acellular component

${ }^{\mathrm{b}}$ molecular pathway

cbiological process

${ }^{d}$ mouse phenotype

${ }^{\mathrm{e}}$ molecular function

inhaled Mitsui-7 MWCNT with four-hour deposited doses on par with those modeled here. Array analysis in lung tissue showed significant upregulation for a broad array of other MMPs, ADAMs and ADAMTSs with MWCNT exposure (Fig. 2d). Furthermore, tissue inhibitors of metalloproteinases (TIMPs) were likewise modulated, with TIMP1 significantly increased at both doses, TIMP2 significantly decreased at both doses, and TIMP3 showing an opposing response between doses. Other proteases are also known to influence remodeling of the ECM after MWCNT exposure, to include lysosomal-released cathepsins [48]. Microarray data showed significant increased at both doses for cathepsins B, H, K, S and Z. Taken together, these data support involvement of multiple proteases, with likely promiscuous activation of one by another and tandem cleavage of common substrates, in generating the peptidomic response observed here.

\section{MWCNT-induced circulating peptidome contributes to cardiovascular endothelial responses}

Bioinformatic functional enrichment analysis was performed to inform on the pathobiological relevance of the circulating peptidomic response to MWCNT. Results classified into five enriched associations (Fig. 3a and Table 2). The largest group of 31 peptides were associated with an extracellular matrix localization and functionally to extracellular matrix (ECM) organization. With ECM reorganization being a principle factor in cardiovascular disease and inflammatory lesion development, it was also fitting that many of the ECM-related measures were among the 27 peptides enriched in association with an abnormal cardiovascular phenotype and altered cardiovascular proliferative biological processes. The results also included 18 peptides reflecting relevance to cell-surface receptor interactions denoting signaling ligands within the peptidome. Peptide-receptor interactions are involved in numerous biological processes, including immune and associated inflammatory signaling, with 22 associated peptides. Lastly, 29 peptides were derived from known exosomal localized proteins, suggesting exosome involvement in systemic MWCNT responses. Collectively, the peptidomic fraction biochemically paralleled our prior published inflammatory and vascular deficit outcomes induced in vivo and ex vivo using the present MWCNT exposure model [14, 23, 25].

After establishing its pathobiological relevance, we then sought to assess the bioactive potential of the serum peptidomic fraction. The enriched peptide fraction was first assessed for its inflammatory potential on primary murine vascular endothelial cells, as previously reported for whole serum [14]. The assay assessed ex vivo endothelial induction across a battery of adhesion molecule and cytokine gene products linked with inflammatory-mediated immune responses. Naïve endothelial cells were treated in culture with the serum peptide fractions of MWCNT-exposed or DM control animals. As observed previously using whole serum from exposed animals [14], the peptide-fraction alone induced significant increases in canonical inflammatory markers 
Ccl2, Vcam1, Icam1, and Tnfa, principally at the $40 \mu \mathrm{g}$ MWCNT dose relative to DM control (Fig. 3b). The magnitude of response was $189 \%(p<0.001), 156 \%$ $(p<0.001), 136 \%(p<0.001)$, and $150 \%(p<0.033)$ of DM control levels for Ccl2, Vcam1, Icam1, and Tnfa, respectively. In contrast, $\mathrm{Ccl} 5$ showed no response to treatment. $T g f b$ and $I l 6$ were additionally assessed in this study, relevant to the MWCNT peptidome's enriched association with immune response processes. Application of the serum peptide fraction induced significant dose-dependent increases in Tgfb expression: $123 \%, p<0.001$ at $10 \mu \mathrm{g} ; 140 \%, p<0.001$ at $40 \mu \mathrm{g}$. In contrast, Il6 levels were absent significant effects of treatment. To support that the inflammatory response was driven by peptide components within the enriched fraction, an aliquot was denatured by reduction and alkylation to disrupt peptide structure, buffer exchanged, and applied to naïve cerebrovascular endothelial cells. Notably, denaturing significantly reversed the peptide fraction's prior inflammatory potential: $C c l 2(40 \mu \mathrm{g}, p<0.001), C c l 5$ $(40 \mu \mathrm{g}, \quad p=0.004)$, Vcam $(40 \mu \mathrm{g}, \quad p<0.001)$, Icam1 $(40 \mu \mathrm{g}, p<0.001)$, Tnfa $(40 \mu \mathrm{g}, p<0.001)$, and Tgfb $(10 \mu \mathrm{g}, p=0.002 ; 40 \mu \mathrm{g}, p<0.001)$ (Fig. 3c).

Next, the serum peptide fraction was assessed for its potential to induce vascular dysfunction as previously tested for whole serum using myography [25]. Naïve aortic rings treated with the serum peptide fraction from $10 \mu \mathrm{g}$ and $40 \mu \mathrm{g}$ dosed animals exhibited significant dysfunction ( $\mathrm{F}=31.2, p<0.001$, main effect of MWCNT exposure) in acetylcholine-mediated dilation (Fig. 3d). The effect was dose-independent, reaching only $57 \%$ the dilation achieved with DM control at either MWCNT dose. As a percent of DM control, the peptide fraction induced the same magnitude deficit as whole serum treatment, which reach just $56 \%$ of DM control relaxation at the $40 \mu \mathrm{g}$ dose [25]. However, the response to the peptide fraction lacked an added deficit previously reported with whole serum at the $10 \mu \mathrm{g}$ dose, which dilated to only $29 \%$ that reached with DM control serum.

\section{MWCNT-responsive exosome-associated peptides coincide with serum exosomal shifts}

As the MWCNT-responsive peptidome was significantly enriched in association with exosomes, we sought to next test an association of this change with a parallel increase in serum exosomes. An enriched exosomal fraction was purified by ultrafiltration followed by sizeexclusion chromatography. The vesicle size distribution fell between 40 and $160 \mathrm{~nm}$ (Fig. 3e) and excluded serum proteins that appear in later fractions between 6 and 20 $\mathrm{nm}$. The measured vesicle distribution matched precisely that accepted for exosomes [49]. MWCNT exposure induced a dose-dependent shift to larger-sized serumexosomal vesicles, reaching significance for the $40 \mu \mathrm{g}$ dose $(18.3 \%$ increase, $p<0.001)$ : DM, $60.4 \pm 1.0 \mathrm{~nm}$; $10 \mu \mathrm{g}, \quad 64.7 \pm 0.9 \mathrm{~nm} ; 71.4 \pm 0.4 \mathrm{~nm}$. Furthermore, the area under the hydrodynamic-size curve increased with MWCNT exposure, relative to DM control, purporting a greater number of exosome-sized serum vesicles, which reach significance at the $40 \mu \mathrm{g}$ dose $(17.5 \%$ increase, $p=0.0284): \mathrm{DM}, 924 \pm 40.6 ; 10 \mu \mathrm{g}, 974 \pm 8.3 ; 40 \mu \mathrm{g}$, $1086 \pm 26.1$. The enriched vesicles were further assessed by transmission electron microscopy (Fig. 3e), with their size and morphology consistent with that previously published for exosomes [50].

\section{Identified thrombospondin fragment relates peptidome relevance to vascular dysfunction}

The induction of endothelial-dependent vasodilatory deficits by serum factors from MWCNT exposed animals has recently been independently confirmed $[25,26]$. The two studies offer complementary mechanistic insight demonstrating the co-dependence between MMP9 activity and TSP-mediated CD36 signaling; yet, a molecular interconnection was not readily apparent. Included within the MWCNT-responsive peptidome reported here was a 59-mer fragment from a TSP2 type-1 domain between residues 402-460. Within TSP type-1 domains are three motifs that enable CD36 binding and modulation: R-x-R, $\mathrm{W}-\mathrm{xx}-\mathrm{W}-\mathrm{xx}-\mathrm{W}$ and CSVTCG motifs [51, 52]. The identified $\mathrm{TSP}_{402-460}$ peptide contains all three motifs (Fig. 4a), which was well characterized by the product ion spectra (Fig. 4b). Significant increases in the $\mathrm{TSP}_{402-460}$ peptide were measured dose-independently within serum at the $10 \mu \mathrm{g}(p=0.002)$ and $40 \mu \mathrm{g}(p<0.001)$ doses, but dose-dependently in BALF at the $40 \mu \mathrm{g}$ dose $(p=0.002)$ relative to DM control (Fig. 4c). The average serum $\mathrm{TSP}_{402-460}$ peptide concentration was then approximated at $24 \mathrm{nM}$ and $20 \mathrm{nM}$ in serum from $10 \mu \mathrm{g}$ and $40 \mu \mathrm{g}$ MWCNT-dosed animals, respectively, using the mean mass spectrometer response to a known peptide concentration. The similar concentration between the two MWCNT doses paralleled the comparable vascular deficit induced by the serum peptide fraction per myography (Fig. 3d). Furthermore, the increased serum amount of the 59-mer peptide at the two MWCNT doses closely profiled MMP9 protein levels within lung tissue (Fig. 2b). Yet known MMP9 cleavage of TSP between residues 306-307 sits well away from the TSP $_{402-460}$ peptide identified here (Fig. 4d), suggesting additional tandem cleavage events by other proteases. TSP is well known to be proteolyzed by other matrix-related enzymes such as MMPs 2 and 14, ADAMTSs 1 and 7, and cathepsin G [53-56]. Moreover, TSP is proteolyzed by immune-cell released and circulating enzymes, for example, elastases, thrombin, plasmin, and HtrA1 [56-60]. The complement of established cleavage sites for these proteases (Fig. 4d), however, are likewise nonspecific to the sequence of the $\mathrm{TSP}_{402-460}$ peptide. Recognizing that the full 


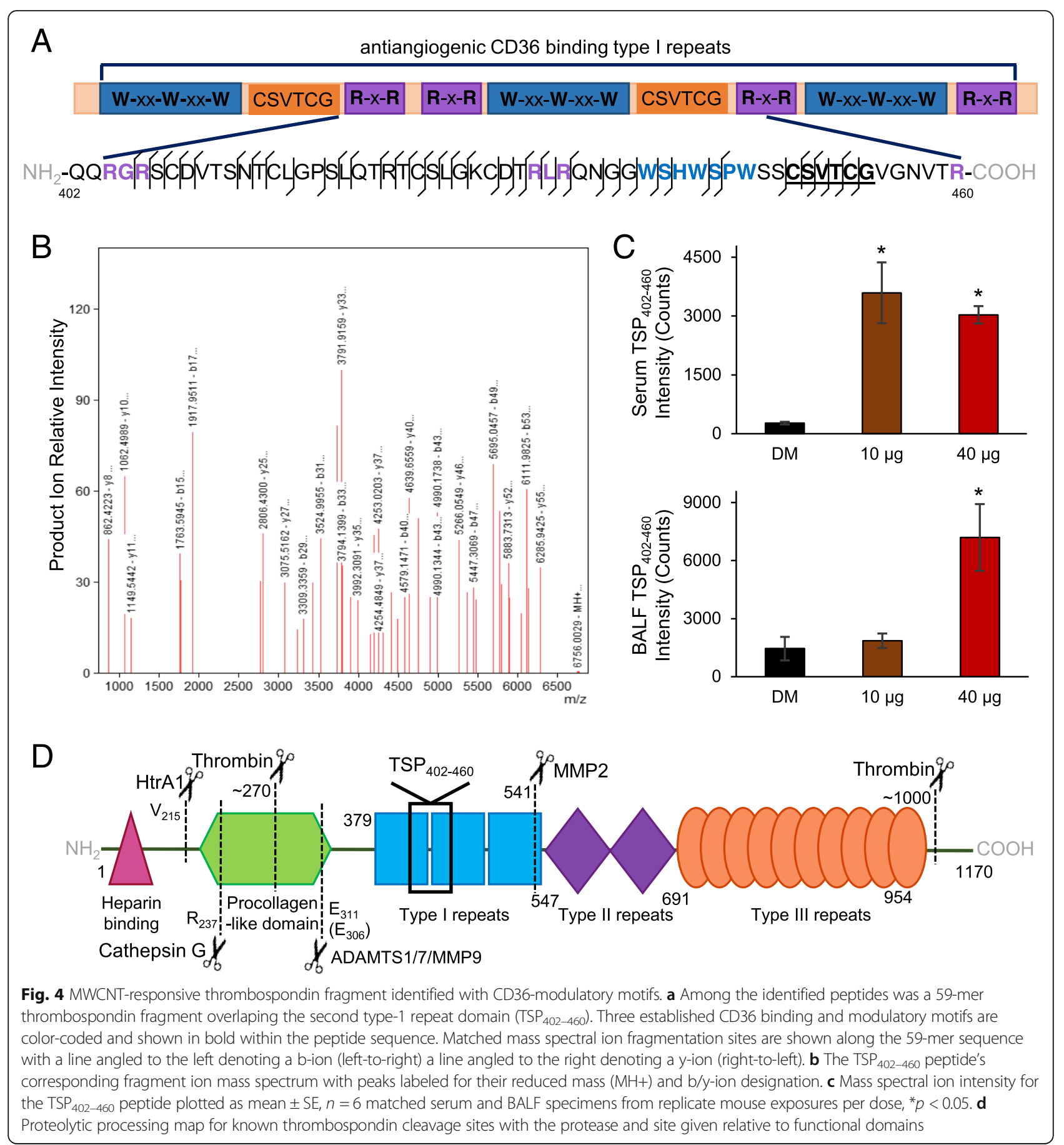

complement of TSP cleavage events, particularly with sequential processing by multiple proteases, cannot be known, we then looked to site prediction informatics. Using the feature-based tool PROSPER [61], we resolved that the c-terminal side of the $\mathrm{TSP}_{402-460}$ peptide is a probable neutrophil elastase cleavage site (cleavage probability score $1.11>0.8$ cutoff for positive prediction at an $82.9 \%$ accuracy for elastase-2). While the full complement of proteolytic processing needed to yield this peptide is expectedly complex, its retained CD36 ligand characteristics exemplify the bioactive potential of the MWCNT-induced circulating peptidome.

\section{Peptide-mediated model of systemic effects following pulmonary nanoparticle exposure}

Cumulatively, findings here establish a complex serum peptidomic response acutely following exposure to MWCNT that conveys bioactivity. Included among the responsive 


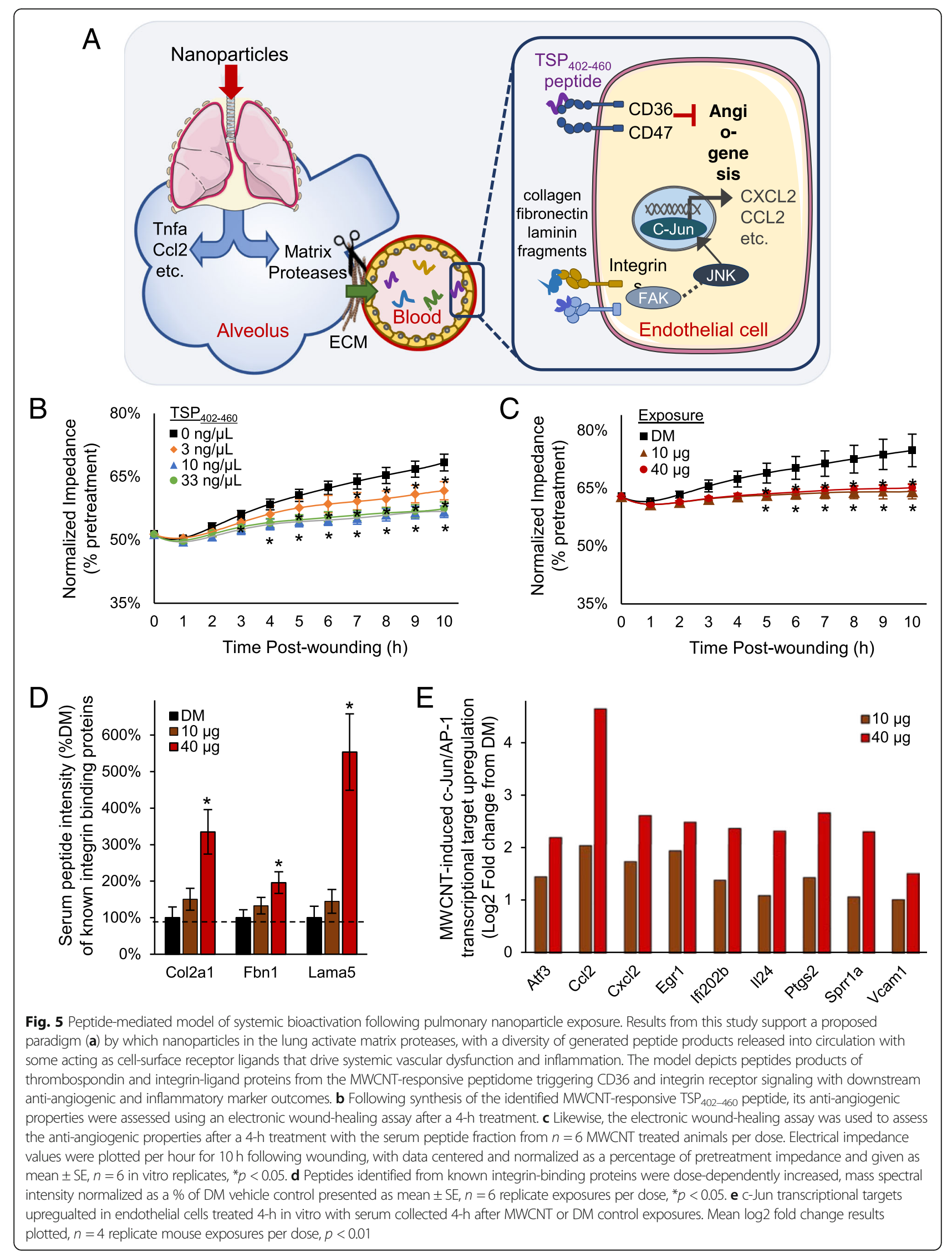


factors are peptide fragments related to abnormal cardiovascular and inflammatory responses, exemplified by the identification of a $\mathrm{TSP}_{402-460}$ peptide with CD36 binding motifs. Results here support consideration of a new peptide-mediated model of systemic effects (Fig. 5a) following nanoparticle exposure. Proposed is that a diverse assortment of matrix remodeling proteases activated following exposure induce peptide byproducts into circulation where they may be further modified yielding an expanded serum peptidomic complexity. The peptidomic response includes cell-surface receptor binding capacity that promotes extra-pulmonary effects. To validate the potential of this model, we synthesized the TSP $402-460$ peptide and applied it in a CD36/CD47-mediated endothelial cell in vitro wound healing angiogenesis assay (Fig. 5b). Addition of the $\mathrm{TSP}_{402-460}$ peptide into the culture media produced a significant anti-angiogenic effect ( $\mathrm{F}=43.5, p<0.001)$, impairing cell regrowth as measured by recovered membrane impedance. Relative to vehicle control, a 6\% deficit reestablishing baseline impedance $10 \mathrm{~h}$ after wounding was observed at a $3 \mathrm{ng} / \mu \mathrm{L}$ dose $(p=0.002)$, a $22 \mathrm{nM}$ concentration in media similar to that estimated in the serum of exposed animals. A 3-fold or greater increase in $\mathrm{TSP}_{402-460}$ concentration saturated the deficit at $12 \%(p<0.001)$. In comparison, the serum peptide fraction from MWCNT exposed animals also significantly inhibited ( $\mathrm{F}=32.7, p<0.001$, main effect of dose) endothelial cell regrowth out to $10 \mathrm{~h}$ after wounding (Fig. 5c). The induced deficit recovering baseline impedance was $9.5 \%(p<0.001)$ relative to DM control, which fell between that induced at 3 and $10 \mathrm{ng} / \mu \mathrm{L} \mathrm{TSP}_{402-}$ 460 peptide. These data establish the bioactive nature of the circulating $\mathrm{TSP}_{402-460}$ peptide that, at least in part, accounts for the anti-angiogenic capacity of the serum peptide fraction.

Looking beyond the TSP peptide, the MWCNT-responsive peptidome was enriched with other fragments of receptor-binding proteins (Fig. 3a). A number of them were derived from known integrin binding collagens, fibronectin and laminins, offering additional potential in mediating observed bioactivity. The MWCNT-response among these peptides was dose-dependent (Fig. 5d) similar to findings from the serum cumulative inflammatory potential assay (Fig. 3b), which contrasted with the dose-independent increase in the $\mathrm{TSP}_{402-460}$ peptide and CD-36 dependent myography (Fig. 3d) and wound healing (Fig. 5c) findings. The MWCNT-responsive peptidome was also significantly enriched in association with interactions upstream of c-Jun transcription (FDR 0.0127) and integrins are known to induce c-Jun-mediated inflammatory factor transcription. Supporting the integrin-ligand potential of the MWCNT-responsive peptidome, in vitro treated endothelial cells exhibited significant dose-dependent upregulation of numerous c-Jun transcriptional products (Fig. 5e) relative to DM control. Together, results here implicate integrin-ligand functionality of the MWCNT-responsive peptidome as an additional part of a broader combinatorial molecular response mediating systemic bioactivity after nanoparticle exposure.

\section{Discussion}

The release of proinflammatory factors from the lung into the circulation, so-called "systemic spill-over", has been posited as a causal link between respirable particle exposure and systemic toxicity, in lieu of, or in addition to particle translocation [6]. Yet uncertainty exists as to the molecular nature and diversity of what is released and how bioactivity is induced. The present study establishes the paradigm that proteolytic byproduct peptides are released from the lung as circulating mediators and potential biomarkers of exposure and/or extra-pulmonary health consequences. Peptide isolation by size fractionation and solid-phase extraction permitted the selective assessment of a peptidomic shift within the blood following MWCNT exposure, validated by unbiased liquid chromatography data-independent mass spectrometry to exclude hydrophobic lipid moieties and proteinaceous material above $7000 \mathrm{Da}$. The enriched peptide fraction conveyed inflammatory potential analogous to that previously demonstrated with whole serum from MWCNT-exposed animals when assessed ex vivo on naïve endothelial cells, despite mass-exclusion of typical cytokine/chemokine mediators. The serum peptide fraction's inflammatory potential, however, was reversed when pretreated to denature the peptide content, confirming peptide involvement. The serum peptide fraction furthermore triggered vasodilatory and endothelial angiogenesis deficits in naïve vessels and cells ex vivo akin to that induced with whole serum. Collectively, these outcomes establish that the peptide fraction alone can convey much of the systemic bioactivity previously reported with full serum collected at the same $4 \mathrm{~h}$ time point after MWCNT exposure using the same model [14, 23, 25]. Moreover, the use of unbiased data-independent tandem mass spectrometry enabled partial identification of the MWCNT-responsive peptidome with a focus on correlated responses in the circulation and lung lavage to direct informatic inquiry towards biomolecular relationships with MWCNT-induced pulmonary pathobiology. The identified peptides were replete with fragments of known cell-surface receptor ligands, illustrated most notably by a peptide from the type- 1 repeat domain of TSP. Containing binding and modulating motifs involved in promoting CD36-dependent endothelial dysfunction, this peptide exemplified a mechanistic role for circulating peptides triggering cell-surface receptor mediated systemic effects.

Nanoparticle exposure has previously been associated with protease activation [41]. Here we assert involvement of a broad array of differentially regulated MMPs, 
ADAMs and ADAMTS and associated metalloprotease inhibitors (TIMPs) in reaction to MWCNT pulmonary exposure. MWCNT can also promote lysosomal protease excretion [48], with several cathepsins involved in ECM remodeling found upregulated in the lung after MWCNT exposure, enhancing the potential diversity of proteolytic processes involved in establishing the MWCNT-responsive peptidome. Sequential multi-protease processing helps to explicate the wide diversity of peptide products discovered responsive to MWCNT, with significant correlation between lung lavage and serum fluid compartments denoting a pulmonary source for part of the circulating peptidomic response. TSP, for example, is an established substrate for at least five matrix metalloproteases and one cathepsin (MMPs 2, 9 and 14; ADAMTSs 1 and 7; cathepsin-G) [53-56]. TSP is also a known substrate for circulating proteases such as thrombin and Htral that also influence ECM reorganization $[58,59]$. While a full decoding of sequential proteolytic processing of TSP falls beyond the scope of the present work, the identified $\mathrm{TSP}_{402-460}$ peptide points to additional, as yet unknown cleavage events. Site prediction software suggests that the c-terminal site represented by this peptide is a probable neutrophil elastase cleavage point, supported by the significant acute influx in lung neurophils using this model [23] and TSP as a known substrate of neutrophil elastase (exact sites unfound) [56, 60]. Altogether, the peptidomic response revealed by these studies represents a post-exposure molecular complexity as yet unappreciated, demarking an equally complex pathobiological response, with substantial diagnostic potential.

Identification of the MWCNT-responsive peptides revealed here is challenged by the stochastic nature of their endogenous generation. Unlike bottom-up proteomic mass spectrometry that involves in-tube digestion with a positionally-restrictive enzyme like trypsin, unknown endogenous byproduct peptides have no stipulated restraints on their beginning or end residues, obfuscating proteomic search engines. To alleviate some of this burden we employed target databases to significantly narrow the sequence search space [62]. We further utilized FDR-controlled peptide match scores rather than protein-level scoring, which is the default of most search engines that assume multiple peptides should match to a single protein in a confident identification. Focused here on peptides measured commonly between serum and BALF to provide selective relevance to pulmonary pathobiology, we were able to identify 73 in connection with known matrix protease substrates and signaling motifs. As a representative sampling of the peptide fraction, there was significant enrichment in matrikine-like fragments from ECM proteins with receptor-ligand functionality. For example, peptides of laminin 5 (Lama5), fibronectin 1 (Fn1) and collagen 3a
(Col3a1) were identified, all ECM proteins known to interact with integrin surface receptors. Furthermore, the MWCNT-responsive peptidome was significantly associated with c-Jun signal transduction. Integrin signaling activates a variety of cellular processes, to include c-Jun n-terminal kinase (JNK) mediated regulation of cell proliferation, migration, and cytokine/chemokine production. ECM-derived peptides acting as circulating integrin ligands can moreover explain dose-dependent endothelial cytokine/chemokine induction observed ex vivo when treating with serum from MWCNT-exposed animals $[14,25]$. In affirmation, microarray analysis of ex vivo treated naïve endothelial cells showed significant upregulation of pathway targets downstream of JNK, reflecting inflammatory marker production and cell stress responses.

The serum peptide fraction alone induced much of the proinflammatory marker response previously reported with whole serum ex vivo treatment $[14,23,25]$. Canonical inflammatory markers Ccl2, Vcam1, Icam1, and Tnfa were all significantly elevated in a dose-dependent manner. Furthermore, the magnitude of response observed here was on-par with that produced by whole serum. Given that the sample fractionation process excluded larger-mass cytokines and chemokines, bioactivity induced by the serum peptide fraction must reflect the presence of alternative proinflammatory ligands such as the dose-dependently increased fragments of integrin-binding proteins Col2a1, Fbn1, and Lama 5 or other cell-surface ligands such as gelactin 3 (Lgals3) or VG-1-related protein (Bmp6), with future studies warranted to clarify details on specific peptide involvement. The ex vivo endothelial proinflammatory response to the peptide fraction, however, was not entirely the same, lacking the robust $\mathrm{Ccl} 5$ upregulation induced with whole serum. We ascertained that the enriched peptide fraction lacked some components of the circulating bioactive profile. It is likely that larger proteolytic fragments, as well as other secreted mediators, were excluded from the peptide fraction. Non-peptide factors also surely contribute to the response diversity across doses and xenobiotic exposures. Yet a majority of the dose-dependent inflammatory response previously reported were reproduced with the serum peptide fraction studied here, substantiating proteolytic product involvement as an indirect mediator conveying a MWCNT response across the lung-blood barrier and acting as cell-surface receptor ligands to promote systemic effects (Fig. 5a). The peptidomic findings here thus help expound on the molecular "systemic spill-over" response as more substantially diverse than previously appreciated.

The identified $\mathrm{TSP}_{402-160}$ fragment was studied here in greater detail as a prototypic example of the MWCNTresponsive peptidome's contribution to cell-surface mediated systemic effects. The 59-mer spans the second of three TSP type-1 repeats, which has been reported as the 
principal CD36 binding site, having the positively charged $\mathrm{W}-\mathrm{xx}-\mathrm{W}-\mathrm{xx}-\mathrm{W}$ and $\mathrm{R}-\mathrm{x}-\mathrm{R}$ motifs needed to interact with the negatively charged CD36 CLESH domain [51, 63]. The fragment also contains the CSVTCG motif found to modulate CD36 activation [52]. Studies show that synthetic peptides derived from TSP type-1 repeat domains exhibit anti-angiogenic properties in a CD36-dependent manner [64], and synthetic peptides as short as 18 amino acids containing the $\mathrm{W}-\mathrm{xx}-\mathrm{W}-\mathrm{xx}-\mathrm{W}$ motif [62] are potent inhibitors of cell proliferation and angiogenesis [65]. Thus the TSP $_{402-460}$ peptide was synthesized and tested for anti-angiogenic properties using a high-precision electrical wound-healing assay. Testing the TSP $402-460$ peptide at a comparable nanomolar concentration in vitro induced a vascular regrowth deficit on par with the serum peptide fraction from MWCNT-exposed animals (Fig. 5c), confirming its bioactivity. We previously published that MWCNT-diminished vasodilatory responses were CD36receptor mediated, with knockout animals exhibiting a muted response [25]. Mandler et al. also found that serum from TSP knockout animals treated with Mitsui-7 MWCNT lacked the ability to induce vasodilatory deficits in naïve aortas $[26,66]$. They also showed that knocking out CD47 also offered vascular protection in ex vivo assays with serum from MWCNT exposed animals, which fits the dependence of TSP-CD36 driven nitric oxide responses on proximal localization of CD47 without the need for direct TSP-CD47 binding [67]. Yet circulating TSP increased by only $50 \% 4 \mathrm{~h}$ following in vivo MWCNT exposure, which is unlikely to dramatically perturb endothelial homeostasis [14]. Furthermore, testing MWCNT-induced vasodilatory dysfunction ex vivo was also largely abolished using serum from MMP9-deficient mice [25], demonstrating a co-dependence of these effects on MMP9 processing. Missing was a factor(s) interlinking TSP, CD36 and MMP9. The identified $\mathrm{TSP}_{402-460}$ fragment peptide offers a unifying mediator of CD36-related systemic pathobiology, increased in serum by over an order in magnitude, and well in excess of the modest 0.5 -fold MWCNT-induced increase in circulating TSP protein [14].

Notably, results from this study emphasize that the peripheral molecular response to nanoparticle exposure is considerably more diverse than previously appreciated. It then fits that systemic bioactivity occurs as a combinatorial response to several circulating factors. The peptide-mediated model in Fig. 5a proposes the involvement of multiple ligand-receptor triggered events. We surmise that this explains the produced dose-independent myography and wound-healing results that were consistent with a dose-independent magnitude of $\mathrm{TSP}_{402-460}$ peptide in circulation, which stands apart from the dose-dependent endothelial induction of pro-inflammatory cytokines and chemokines that are not downstream of CD36-receptor signaling. Inflammatory marker production is, however, downstream of integrin-mediated c-Jun transcriptional activity. The MWCNT-responsive peptidome was enriched in peptides from receptor binding proteins, particularly integrin ligands upstream of c-Jun. The identified fragments of known integrin binding ligands exhibited dose-dependent increases, warranting follow-up investigation as to the combinatorial bioactivity across the responsive peptidome.

Unexpectedly, we found an enriched association between the MWCNT-responsive peptidome and exosomal protein fragments. Exosomes play a pivotal role in cellular communication by delivering bioactive molecules such as mRNA, miRNA, proteins and perhaps peptides to distant tissues. Yet exosomal involvement in response to inhaled xenobiotics remains understudied; though, it was recently published that bronchial epithelial cells release exosomes when challenged with cigarette smoke extract [68]. It turns out that very few proteins, mainly surfactant-related, are specific enough to demark a vesicular lung origin. While the data here cannot affirm lung specificity, they do suggest it, with 28 of 29 exosome-associated peptides derived from proteins of known lung expression and $77.3 \%$ with a higher than average abundance (Tissue Atlas, www.proteinatlas.org). Presently, we found an increase in the size and abundance of serum exosomes following MWCNT exposure. An increase in diameter infers a greater volumetric increase in vesicle capacity, suggesting a quantitative shift in exosomal cargo as seen under other pathological conditions [69-71]. These findings demonstrate that MWCNT exposure alters the serum exosome population, implicating their potential involvement in systemic pathobiology. Exosomes also carry matrix proteases and thus may play a further role in peptidome processing [71]. Follow-up studies are needed to determine whether exosome-related peptides found here reflect induced surface protein cleavage or rather a shift in peptide exosomal packaging with separate bioactive capacity.

Further studies are needed to address additional questions raised from the initial findings here, to include assessing ligand functions of other identified peptides and determining selectivity within the peptidomic response across different pulmonary exposures - whether different carbon nanomaterials or other types of nanoparticles. Different exposures are likely to exhibit a diversity of proteolytic events and a correspondingly distinctive peptidomic signature that is consistent with differences in pulmonary injury. Modulation of MWCNT dose was alone sufficient to shift the complexity of the peptidomic response, and time after insult is yet another key variable that needs to be examined. Perhaps peptidomic distinctions between materials would be more evident at later time points following what may be a more generalized acute-phase response studied here. It should also be noted that $77 \%$ of the MWCNT-responsive peptidome common 
between serum and BALF was not readily identified, and that the added peptidomic complexity observed exclusively in the circulation, relative to BALF, remains to be examined. As discussed earlier, endogenous peptides are particularly difficult to identify due to the vast sequencesearch space involved. We used smaller targeted databases to facilitate identification; however, products outside those focused databases go unidentified. Informatic approaches to improve search selectivity are also needed to address identification of post-translational modified peptides. Blood polypeptides are often glycosylated, a particularly diverse modification that exacerbates the sequence search space issue and further complicates comprehensive identification. Ultimately, results here establish existence of a diverse and bioactive circulating peptidomic response following pulmonary nanoparticle insult, providing foundation for more through characterization of its mechanistic role in driving systemic pathobiology.

\section{Conclusions}

Findings here substantiate proteolytic peptide involvement in mediating systemic consequences of nanoparticle exposure. A wide variety of inhaled xenobiotics upregulate matrix proteases and produce various systemic effects. Agents from titanium dioxide to diesel exhaust have been shown to induce extra-pulmonary inflammation and cardiovascular impairments much as reported here for MWCNT [27, 72-74]. Indeed, many insoluble metal and engineered nanoparticles $\mathrm{Au}, \mathrm{Ag}$, titanium dioxide, ultrafine carbon and other CNTs, etc.) induce pulmonary pathology that may be accompanied by proteolytic generation and release of bioactive peptides. Once in circulation, fragments such as the $\mathrm{TSP}_{402-460}$ peptide or those from integrin ligands induce cell-surface receptor mediated systemic stress and inflammation, driving particulate exposure's adjuvant role in promoting everything from cardiovascular to neurodegenerative diseases. Furthermore, the revealed existence of a pathological peptidomic response to nanoparticle exposure represents a highly diverse and dosedependent molecular source of putative biomarkers that may provide greater specificity than previously available [9]. More thorough characterization of circulatory factors is warranted to assess the role of peptide byproducts mediating systemic disease following pulmonary insult to a broader array of occupational and environmental xenobiotic agents.

\section{Abbreviations}

BALF: Bronchoalveolar lavage fluid; CCl2: C-C motif chemokine ligand 2; CC15: C-C motif chemokine ligand 5; DM: Dispersion media; ECM: Extracellular matrix; FDR: False discovery rate; II6: Interleukin 6; MMP: Matrix metalloproteinase; MWCNT: Multi-walled carbon nanotubes; Tgfb: Transforming growth factor beta; Tnfa: Tumor necrosis factor alpha; TSP: Thrombospondin; Vcam 1: Vascular cell adhesion molecule 1

\section{Acknowledgements}

AKO and CGC thank Drs. Hu Yang and Juan Wang for access and assistance with the Zetasizer instrument and Judy Williams for assistance with electron microscopy. EM and AKO thank Pavel Lizhnyak and Pallavi Pilaka for assistance with informatics and sample processing. The authors thank Guy Herbert for performing the ECIS assays.

\section{Funding}

This study was funded by grants from the National Institute for Occupational Safety and Health (OH010495 to A.K.O. and M.J.C. and NTRC 939ZXFL to A.E.). The findings and conclusions in this report are those of the authors and do not necessarily represent the official position of the National Institute for Occupational Safety and Health, Centers for Disease Control and Prevention.

\section{Availability of data and materials}

The datasets used and/or analyzed during the current study are available from the corresponding author on reasonable request.

\section{Authors' contributions}

EM and AKO prepared the manuscript with further input from TY, AE and MJC. EM, TY, PPM, CGC, PCZ-E, AE and MJC contributed to the design of aspects of the study. LB and AE completed the animal modeling. PPM, EM and AKO performed the biofluid preparation and mass spectrometric analysis. EM and AKO completed the mass spectral data processing and informatic interrogation. AV provided informatic software support. TY performed the vascular-related functional assessments. CGC and EM carried out the exosome processing and analyses. PCZ-E completed the microarray experimentation.

\section{Ethics approval}

All animal procedures were approved by the Institutional Animal Care and Use Committee of the National Institute for Occupational Safety and Health and were conducted in accordance with the U.S. Public Health Service Policy on Humane Care and Use of Laboratory Animals and the National Institutes of Health Guide for the Care and Use of Laboratory Animals.

\section{Consent for publication}

Not applicable.

\section{Competing interests}

The authors declare that they have no competing interests.

\section{Publisher's Note}

Springer Nature remains neutral with regard to jurisdictional claims in published maps and institutional affiliations.

\section{Author details}

${ }^{1}$ Department of Anatomy and Neurobiology, Virginia Commonwealth University, Box 980709, Richmond, VA 23298-0709, USA. ²Department of Pharmaceutical Sciences, University of New Mexico, Albuquerque, NM 87131, USA. ${ }^{3}$ Pathology and Physiology Research Branch, National Institute for Occupational Safety and Health, Morgantown, WV 26505, USA.

Received: 28 September 2018 Accepted: 10 May 2019

Published online: 29 May 2019

\section{References}

1. Hoet PH, Brüske-Hohlfeld I, Salata OV. Nanoparticles - known and unknown health risks. J Nanobiotechnology. 2004;2:12

2. Daigle CC, Chalupa DC, Gibb FR, Morrow PE, Oberdörster G, Utell MJ, et al. Ultrafine particle deposition in humans during rest and exercise. Inhal Toxicol. 2003;15:539-52.

3. Chalupa DC, Morrow PE, Oberdorster G, Utell MJ, Frampton MW. Ultrafine particle deposition in subjects with asthma. Environ Health Perspect. 2004; 112:879-82.

4. Stone V, Miller MR, Clift MJD, Elder A, Mills NL, Møller P, et al. Nanomaterials versus ambient ultrafine particles: an opportunity to exchange toxicology knowledge. Environ Health Perspect. 2017;125:1-17.

5. Chen R, Hu B, Liu Y, Xu J, Yang G, Xu D, et al. Beyond PM2.5: the role of ultrafine particles on adverse health effects of air pollution. Biochim Biophys Acta. 2016;1860:2844-55. 
6. Brook RD, Rajagopalan S, 3rd CAP, Brook JR, Bhatnagar A, Diez-Roux AV, et al. Particulate matter air pollution and cardiovascular disease: an update to the scientific statement from the American Heart Association. Circulation. 2010;121:2331-78.

7. Block ML, Elder A, Auten RL, Bilbo SD, Chen H, Chen JC, et al. The outdoor air pollution and brain health workshop. Neurotoxicology. 2012;33:972-84.

8. Donaldson K, Aitken R, Tran L, Stone V, Duffin R, Forrest G, et al. Carbon nanotubes: a review of their properties in relation to pulmonary toxicology and workplace safety. Toxicol Sci. 2006;92:5-22.

9. Erdely A, Liston A, Salmen-Muniz R, Hulderman T, Young S-H, Zeidler-Erdely $P C$, et al. Identification of systemic markers from a pulmonary carbon nanotube exposure. J Occup Environ Med. 2011;53(Suppl 6):S80-6.

10. Li Z, Hulderman T, Salmen R, Chapman R, Leonard SS, Young SH, et al. Cardiovascular effects of pulmonary exposure to single-wall carbon nanotubes. Environ Health Perspect. 2007;115:377-82.

11. Stapleton PA, Minarchick VC, Cumpston AM, McKinney W, Chen BT, Sager TM, et al. Impairment of coronary arteriolar endothelium-dependent dilation after multi-walled carbon nanotube inhalation: a time-course study. Int J Mol Sci. 2012;13:13781-803.

12. Liao H-Y, Chung Y-T, Lai C-H, Wang S-L, Chiang H-C, Li L-A, et al. Six-month follow-up study of health markers of nanomaterials among workers handling engineered nanomaterials. Nanotoxicology. 2014;8:100-10

13. Reddy AR, Krishna DR, Reddy YN, Himabindu V. Translocation and extra pulmonary toxicities of multi wall carbon nanotubes in rats. Toxicol Mech Methods. 2010;20:267-72.

14. Aragon MJ, Topper L, Tyler CR, Sanchez B, Zychowski K, Young T, et al. Serum-borne bioactivity caused by pulmonary multiwalled carbon nanotubes induces neuroinflammation via blood-brain barrier impairment. Proc Natl Acad Sci U S A. 2017;114:E1968-76.

15. Nemmar A, Vanbilloen $H$, Hoylaerts MF, Hoet PH, Verbruggen A, Nemery B. Passage of intratracheally instilled ultrafine particles from the lung into the systemic circulation in hamster. Am J Respir Crit Care Med. 2001;164:1665-8.

16. Deng $X$, Jia G, Wang $H$, Sun $H$, Wang $X$, Yang $S$, et al. Translocation and fate of multi-walled carbon nanotubes in vivo. Carbon. 2007:45:1419-24.

17. Pauluhn J. Multi-walled carbon nanotubes (Baytubes): approach for derivation of occupational exposure limit. Regul Toxicol Pharmacol. 2010;57: 78-89.

18. Brown JS, Zeman KL, Bennett WD. Ultrafine particle deposition and clearance in the healthy and obstructed lung. Am J Respir Crit Care Med. 2002;166:1240-7.

19. Mercer RR, Scabilloni JF, Hubbs AF, Wang L, Battelli LA, McKinney W, et al. Extrapulmonary transport of MWCNT following inhalation exposure. Part Fibre Toxicol. 2013;10:38

20. Upadhyay S, Stoeger T, Harder V, Thomas RF, Schladweiler MC, SemmlerBehnke $M$, et al. Exposure to ultrafine carbon particles at levels below detectable pulmonary inflammation affects cardiovascular performance in spontaneously hypertensive rats. Part Fibre Toxicol. 2008;5:19.

21. Khandoga A, Stoeger T, Khandoga AG, Bihari P, Karg E, Ettehadieh D, et al. Platelet adhesion and fibrinogen deposition in murine microvessels upon inhalation of nanosized carbon particles. J Thromb Haemost. 2010;8:1632-40.

22. Mitchell LA, Lauer FT, Burchiel SW, McDonald JD. Mechanisms for how inhaled multiwalled carbon nanotubes suppress systemic immune function in mice. Nat Nanotechnol. 2009;4:451-6.

23. Erdely A, Hulderman T, Salmen R, Liston A, Zeidler-Erdely PC, SchweglerBerry $D$, et al. Cross-talk between lung and systemic circulation during carbon nanotube respiratory exposure. Potential biomarkers. Nano Lett. 2009;9:36-43.

24. Walker VG, Li Z, Hulderman T, Schwegler-Berry D, Kashon ML, Simeonova PP. Potential in vitro effects of carbon nanotubes on human aortic endothelial cells. Toxicol Appl Pharmacol. 2009;236:319-28.

25. Aragon M, Erdely A, Bishop L, Salmen R, Weaver J, Liu J, et al. MMP-9dependent serum-borne bioactivity caused by multiwalled carbon nanotube exposure induces vascular dysfunction via the CD36 scavenger receptor. Toxicol Sci. 2016;150:488-98

26. Mandler WK, Nurkiewicz TR, Porter DW, Olfert IM. Thrombospondinmediates multi-walled carbon nanotube induced impairment of arteriolar dilation. Nanotoxicology. 2017;11:112-22.

27. Tham A, Lullo D, Dalton S, Zeng S, van Koeverden I, Arjomandi M. Modeling vascular inflammation and atherogenicity after inhalation of ambient levels of ozone: exploratory lessons from transcriptomics. Inhal Toxicol. 2017;29:96-105.
28. McDonald JD, Doyle-Eisele M, Campen MJ, Seagrave J, Holmes T, Lund A, et al. Cardiopulmonary response to inhalation of biogenic secondary organic aerosol. Inhal Toxicol. 2010;22:253-65.

29. Remane D, Wissenbach DK, Peters FT. Recent advances of liquid chromatography-(tandem) mass spectrometry in clinical and forensic toxicology — an update. Clin Biochem. 2016;49:1051-71.

30. Porter DW, Hubbs AF, Mercer RR, Wu N, Wolfarth MG, Sriram K, et al. Mouse pulmonary dose- and time course-responses induced by exposure to multiwalled carbon nanotubes. Toxicology. 2010;269:136-47.

31. Ottens AK, Stafflinger JE, Griffin HE, Kunz RD, Cifu DX, Niemeier JP. Postacute brain injury urinary signature: a new resource for molecular diagnostics. J Neurotrauma. 2014;31:782-8.

32. Distler U, Kuharev J, Navarro P, Tenzer S. Label-free quantification in ion mobility-enhanced data-independent acquisition proteomics. Nat Protoc. 2016;11:795-812.

33. Cortes DF, Landis MK, Ottens AK. High-capacity peptide-centric platform to decode the proteomic response to brain injury. Electrophoresis. 2012;33: 3712-9.

34. Rawlings ND, Barrett AJ, Finn R. Twenty years of the MEROPS database of proteolytic enzymes, their substrates and inhibitors. Nucleic Acids Res. 2016; 44:D343-50.

35. Petersen TN, Brunak S, Von Heijne G, Nielsen H. SignalP 4.0: discriminating signal peptides from transmembrane regions. Nat Methods. 2011:8:785-6.

36. Wenger CD, Coon JJ. A proteomics search algorithm specifically designed for high-resolution tandem mass spectra. J Proteome Res. 2013;12:1377-86.

37. Strohalm M, Kavan D, Novák P, Volný M, Havlíček V. mMass 3: a crossplatform software environment for precise analysis of mass spectrometric data. Anal Chem. 2010;82:4648-51.

38. Chen J, Bardes EE, Aronow BJ, Jegga AG. ToppGene suite for gene list enrichment analysis and candidate gene prioritization. Nucleic Acids Res. 2009;37:W305-11.

39. Szklarczyk D, Morris JH, Cook H, Kuhn M, Wyder S, Simonovic M, et al. The STRING database in 2017: quality-controlled protein-protein association networks, made broadly accessible. Nucleic Acids Res. 2017;45:D362-8.

40. Erdely A, Dahm M, Chen BT, Zeidler-Erdely PC, Fernback JE, Birch ME, et al. Carbon nanotube dosimetry: from workplace exposure assessment to inhalation toxicology. Part Fibre Toxicol. 2013;10:53.

41. Zeidler-Erdely PC, Kashon ML, Li S, Antonini JM. Response of the mouse lung transcriptome to welding fume: effects of stainless and mild steel fumes on lung gene expression in a/J and C57BL/6J mice. Respir Res. 2010;11:70.

42. Zychowski KE, Sanchez B, Pedrosa RP, Lorenzi-Filho G, Drager LF, Polotsky $\mathrm{V}$, et al. Serum from obstructive sleep apnea patients induces inflammatory responses in coronary artery endothelial cells. Atherosclerosis. 2016;254:59-66.

43. Saeed Al, Sharov V, White J, Li J, Liang W, Bhagabati N, et al. TM4: a free, open-source system for microarray data management and analysis. Biotechniques. 2003:34:374-8.

44. Benjamini Y, Hochberg Y. Controlling the false discovery rate: a practical and powerful approach to multiple testing. J R Stat Soc B. 1995;57:289-300.

45. Govender P, Dunn MJ, Donnelly SC. Proteomics and the lung: analysis of bronchoalveolar lavage fluid. Proteomics Clin Appl. 2009;3:1044-51.

46. Jeong K, Kim S, Bandeira N. False discovery rates in spectral identification. BMC Bioinformatics. 2012;13(Suppl 16):S2.

47. Ricard-Blum S, Salza R. Matricryptins and matrikines: biologically active fragments of the extracellular matrix. Exp Dermatol. 2014;23:457-63.

48. Mu QX, Broughton DL, Yan B. Endosomal leakage and nuclear translocation of multiwalled carbon nanotubes: developing a model for cell uptake. Nano Lett. 2009;9:4370-5.

49. Colombo M, Raposo G, Théry C. Biogenesis, secretion, and intercellular interactions of exosomes and other extracellular vesicles. Annu Rev Cell Dev Biol. 2014;30:255-89.

50. Park JA, Sharif AS, Tschumperlin DJ, Lau L, Limbrey R, Howarth P, et al. Tissue factor-bearing exosome secretion from human mechanically stimulated bronchial epithelial cells in vitro and in vivo. J Allergy Clin Immunol. 2012;130:1375-83.

51. Klenotic PA, Page RC, Li W, Amick J, Misra S, Silverstein RL. Molecular basis of antiangiogenic thrombospondin-1 type 1 repeat domain interactions with CD36. Arterioscler Thromb Vasc Biol. 2013;33:1655-62.

52. Asch AS, Silbiger S, Heimer E, Nachman RL. Thrombospondin sequence motif (CSVTCG) is responsible for CD36 binding. Biochem Biophys Res Commun. 1992;182:1208-17. 
53. Prudova A, auf dem Keller U, Butler GS, Overall CM. Multiplex N-terminome analysis of MMP-2 and MMP-9 substrate Degradomes by iTRAQ-TAlLS quantitative proteomics. Mol Cell Proteomics. 2010;9:894-911.

54. Butler GS, Dean RA, Tam EM, Overall CM. Pharmacoproteomics of a metalloproteinase Hydroxamate inhibitor in breast Cancer cells: dynamics of membrane type 1 matrix metalloproteinase-mediated membrane protein shedding. Mol Cell Biol. 2008;28:4896-914.

55. Lee NV, Sato M, Annis DS, Loo JA, Wu L, Mosher DF, et al. ADAMTS1 mediates the release of antiangiogenic polypeptides from TSP1 and 2 EMBO J. 2006;25:5270-83.

56. Seif K, Alidzanovic L, Tischler B, Ibrahim N, Zagrapan B, Rauscher S, et al. Neutrophil-mediated proteolysis of Thrombospondin-1 promotes platelet adhesion and String formation. Thromb Haemost. 2018;118:2074-85.

57. Bonnefoy A, Legrand C. Proteolysis of subendothelial adhesive glycoproteins (fibronectin, thrombospondin, and von Willebrand factor) by plasmin, leukocyte cathepsin G, and elastase. Thromb Res Pergamon. 2000;98:323-32.

58. Lawler J, Connolly JE, Ferro P, Derick LH. Thrombin and chymotrypsin interactions with thrombospondin. Ann N Y Acad Sci. 1986;485:273-87.

59. 'yi CC, Melo E, Jakob P, Friedlein A, Elsässer B, Goettig P, et al. N-Terminomics identifies HtrA1 cleavage of thrombospondin-1 with generation of a proangiogenic fragment in the polarized retinal pigment epithelial cell model of age-related macular degeneration. Matrix Biol. 2018;70:84-101.

60. El Rayes T, Catena R, Lee S, Stawowczyk M, Joshi N, Fischbach C, et al. Lung inflammation promotes metastasis through neutrophil protease-mediated degradation of tsp-1. Proc Natl Acad Sci. 2015;112:16000-5.

61. Song J, Tan H, Perry AJ, Akutsu T, Webb Gl, Whisstock JC, et al. PROSPER: an integrated feature-based tool for predicting protease substrate cleavage sites. PLoS One. 2012;7:e50300.

62. Vogel T, Guo NH, Krutzsch HC, Blake DA, Hartman J, Mendelovitz S, et al. Modulation of endothelial cell proliferation, adhesion, and motility by recombinant heparin-binding domain and synthetic peptides from the type I repeats of thrombospondin. J Cell Biochem. 1993;53:74-84.

63. Tan K, Lawler J. The interaction of thrombospondins with extracellular matrix proteins. J Cell Commun Signal. 2009;3:177-87.

64. Miao WM, Seng WL, Duquette M, Lawler P, Laus C, Lawler J. Thrombospondin-1 type 1 repeat recombinant proteins inhibit tumor growth through transforming growth factor-beta-dependent and -independent mechanisms. Cancer Res. 2001;61:7830-9.

65. Hugo CP, Pichler RP, Schulze-Lohoff E, Prols F, Adler S, Krutsch HC, et al. Thrombospondin peptides are potent inhibitors of mesangial and glomerular endothelial cell proliferation in vitro and in vivo. Kidney Int. 1999;55:2236-49.

66. Mandler WK, Nurkiewicz TR, Porter DW, Kelley EE, Olfert IM. Microvascular dysfunction following multiwalled carbon nanotube exposure is mediated by Thrombospondin-1 receptor CD47; 2018. p. 1-10.

67. Isenberg JS, Martin-Manso G, Maxhimer JB, Roberts DD. Regulation of nitric oxide signalling by thrombospondin 1: implications for anti-angiogenic therapies. Natl Rev. 2009;9:182-94.

68. Benedikter BJ, Volgers C, van Eijck PH, Wouters EFM, Savelkoul PHM, Reynaert NL, et al. Cigarette smoke extract induced exosome release is mediated by depletion of exofacial thiols and can be inhibited by thiolantioxidants. Free Radic Biol Med. 2017;108:334-44.

69. Taylor DD, Gercel-Taylor C. MicroRNA signatures of tumor-derived exosomes as diagnostic biomarkers of ovarian cancer. Gynecol Oncol. 2008;110:13-21.

70. Thomas S, Liao Z, Clark D, Chen Y, Samadani R, Mao L, et al. Exosomal proteome profiling: a potential multi-marker cellular phenotyping tool to characterize hypoxia-induced radiation resistance in breast Cancer. Proteomes. 2013;1:87-108.

71. Yuana Y, Sturk A, Nieuwland R. Extracellular vesicles in physiological and pathological conditions. Blood Rev. 2013;27:31-9.

72. Knuckles TL, Yi J, Frazer DG, Leonard HD, Chen BT, Castranova V, et al. Nanoparticle inhalation alters systemic arteriolar vasoreactivity through sympathetic and cyclooxygenase-mediated pathways. Nanotoxicology. 2012;6:724-35

73. Tyler CR, Zychowski KE, Sanchez BN, Rivero V, Lucas S, Herbert G, et al. Surface area-dependence of gas-particle interactions influences pulmonary and neuroinflammatory outcomes. Part Fibre Toxicol. 2016;13:1-18.

74. Lund AK, Lucero J, Lucas S, Madden MC, McDonald JD, Seagrave JC, et al. Vehicular emissions induce vascular MMP-9 expression and activity associated with endothelin-1-mediated pathways. Arterioscler Thromb Vasc Biol. 2009;29:511-7.

Ready to submit your research? Choose BMC and benefit from:

- fast, convenient online submission

- thorough peer review by experienced researchers in your field

- rapid publication on acceptance

- support for research data, including large and complex data types

- gold Open Access which fosters wider collaboration and increased citations

- maximum visibility for your research: over $100 \mathrm{M}$ website views per year

At BMC, research is always in progress.

Learn more biomedcentral.com/submissions 